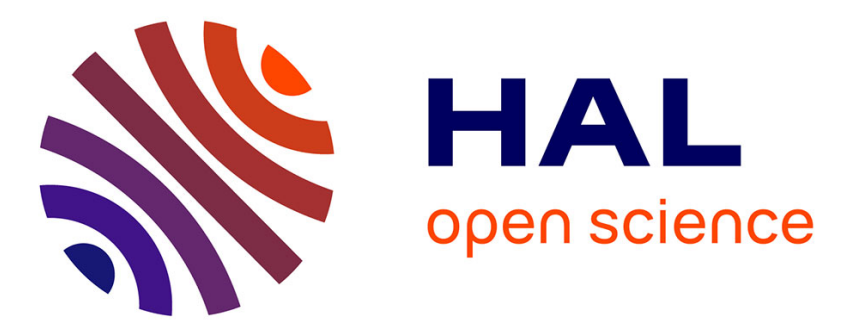

\title{
A survey of geminiviruses and associated satellite DNAs in the cotton-growing areas of northwestern India
}

\author{
Valerio Zaffalon, Sunil Kumar Mukherjee, Vanga Siva Reddy, Jeremy R.
} Thompson, Mark Tepfer

\section{- To cite this version:}

Valerio Zaffalon, Sunil Kumar Mukherjee, Vanga Siva Reddy, Jeremy R. Thompson, Mark Tepfer. A survey of geminiviruses and associated satellite DNAs in the cotton-growing areas of northwestern India. Archives of Virology, 2012, 157 (3), pp.483-495. 10.1007/s00705-011-1201-y . hal-02651901

\section{HAL Id: hal-02651901 \\ https://hal.inrae.fr/hal-02651901}

Submitted on 29 May 2020

HAL is a multi-disciplinary open access archive for the deposit and dissemination of scientific research documents, whether they are published or not. The documents may come from teaching and research institutions in France or abroad, or from public or private research centers.
L'archive ouverte pluridisciplinaire HAL, est destinée au dépôt et à la diffusion de documents scientifiques de niveau recherche, publiés ou non, émanant des établissements d'enseignement et de recherche français ou étrangers, des laboratoires publics ou privés.

\section{(ㄷ)(1) $\$$}

Distributed under a Creative Commons Attribution - NonCommercial| 4.0 International 


\title{
A Survey of Geminiviruses and Associated Satellite DNAs in the Cotton-Growing Areas of Northwestern India
}

\author{
Valerio Zaffalon $^{1,2}$, Sunil Kumar Mukherjee ${ }^{3}$, Vanga Siva Reddy ${ }^{3}$, Jeremy R. Thompson ${ }^{1,4}$ and \\ Mark Tepfer ${ }^{1,5,6 *}$. \\ ${ }^{1}$ Plant Virology Group, ICGEB Biosafety Outstation, Via Piovega 23, 31056 Ca’ Tron di Roncade, \\ Italy. \\ ${ }^{2}$ Department of Environmental Agronomy and Crop Science, University of Padova, Viale \\ dell’Università 16, 35020 Legnaro (Padova), Italy \\ ${ }^{3}$ Plant Biology Group, ICGEB Campus, Aruna Asaf Ali Marg, 110067 New Delhi, India. \\ ${ }^{4}$ Plant Science 334, Department of Plant Pathology and Plant-Microbe Biology, Cornell University, \\ Ithaca, $14853 \mathrm{NY}$, USA. \\ ${ }^{5}$ Institut Jean-Pierre Bourgin UMR1318, INRA-Versailles, 78026 Versailles Cedex, France. \\ ${ }^{6}$ INRA, UR407 Pathologie Végétale, 84140 Montfavet cedex, France \\ *Corresponding Authors: jrt36@cornell.edu \\ Mark.Tepfer@versailles.inra.fr
}

\begin{abstract}
Severe symptoms of Cotton leaf curl disease (CLCuD) are caused by the association of a single-stranded circular DNA satellite (betasatellite) with a helper begomovirus. In this study we analyzed 40 leaf samples (primarily cotton with CLCuD symptoms and other plants growing close by) from four sites between New Delhi and the Pakistan/India border, using rolling circle amplification (RCA) and PCR. In total, the complete sequences of 12 different helper viruses, eight alphasatellites, and one betasatellite from five different plant species were obtained. A recombinant helper virusmolecule found in okra, a novel alphasatellite-related DNA from croton, and a circular DNA of 941 nucleotides isolated from clerodendrum are also described. This is the first report of the presence of both DNA components (Helper virus and betasatellite) associated with resistancebreaking $\mathrm{CLCuD}$ in India, and highlights the need for further work to combat its damage and spread.
\end{abstract}

Keywords: Begomovirus, Cotton leafcurl disease, Burewala, India, betasatellite, alphasatellite.

\section{Introduction}

Geminiviruses and their associated satellites present modern agriculture with important challenges, inducing a variety of diseases in tropical and sub-tropical regions [25, 30, 34]. Economic losses caused by the geminiviral cotton leaf curl disease (CLCuD) are some of the most significant of any plant virus. In the Indian subcontinent it was first identified around the Pakistani city of Multan in 1986 [16], and has since spread rapidly; in 1991 in the Pakistani Punjab the disease affected 14,000 ha out of a total growing area of 2.5 million ha, and two years later had spread to affect an overall area of 202,000 ha, resulting in a reduction in cotton yield of 29\% [7]. In the following years the disease continued to spread in the Punjab and to the surrounding Pakistani regions, and in 1993 was first reported across the border in India, in Sriganganagar, Rajasthan [19]. Between 1992 and 1997, the economic loss due to CLCuD in Pakistan was calculated to be about 5 billion US dollars [7]. The establishment of the disease was assumed to be principally due to the introduction of high yielding, highly CLCuD-susceptible varieties of cotton (Gossypium hirsutum), in place of the native, resistant cotton species G. arboreum, a problem only temporarily addressed by the development of new tolerant/resistant G. hirsutum varieties [2-3]. Resistance subsequently 
began to break down in 2001-2002, which has been ascribed to the emergence of Cotton leaf curl Burewala virus (CLCuBuV) and a novel recombinant betasatellite [23-24].

The etiology of CLCuD has been demonstrated to involve two infectious circular geminiviral DNAs. The first component is the helper virus (a monopartite begomovirus), which is autonomous and self-replicating, and by itself induces little or no symptoms in cotton. The second component, a betasatellite, though entirely dependent on the helper virus for replication, encapsidation, transmission by the whitefly Bemisia tabaci, and movement, is critical for symptom expression [8, 33]. In addition there is a third component associated with viruses causing CLCuD, an alphasatellite (also referred to as DNA 1), which depends on the helper virus for encapsidation, movement, and transmission, but in contrast to the betasatellite, replicates autonomously [22]. Alphasatellites appear to play no major role in disease maintenance or pathogenicity, although it has been demonstrated that they can reduce the accumulation the helper virus [42], possibly by competing for cellular resources which as a result attenuate the severity of the disease, playing a role similar to that of the defective interfering DNAs [9, 36]. CLCuD continues to be of primary concern to Indian and Pakistani cotton growers, and as yet there are still no positive signs that it can be effectively controlled - in Pakistan new varieties resistant (rather than tolerant) to the 2001-2002 resistance-breaking CLCuBuV have failed to materialize [2]. In India, where less work in general has been carried out on CLCuD compared to Pakistan, reports have so far identified a variety of viruses associated with the disease, namely, Cotton leaf curl Rajasthan virus (CLCuRaV), Cotton leaf curl Multan virus (CLCuMuV), Cotton leaf curl Kokhran virus (CLCuKoV), Tomato leaf curl Bangalore virus (ToLCBV), Tomato leaf curl Bangalore virus (ToLCBV) [1, 18-19]. This situation contrasts with the present state of the disease in Pakistan, where CLCuBuV now predominates [4].

The aim of this study was to increase our knowledge of CLCuD through a molecular epidemiology study involving the characterization of infectious circular DNA genomes present in a number of plants located in and around infected cotton fields of Northwestern India, using both PCR and rolling circle amplification (RCA). This information will improve our understanding of virus diversity and evolution, and therefore assist in the long-term in the eventual development of durable and safe resistance to the disease.

\section{Materials and Methods Samples}

Leaves of symptomatic and asymptomatic plants were collected in Northwestern India on 17-18 September 2007, in fields in or near the cities of Hisar and Sirsa (Haryana), Kumiharwala (a village in Muktsar district, Punjab) and Sriganganagar (Rajasthan) (Fig. 1, Table 1). Incidence of CLCuD symptoms was low in cotton fields in or near Hisar, and very high at Sirsa, Kumiharwala and Sriganganagar, where it was close to $100 \%$. In Hisar, cotton, okra and croton samples were from an agricultural context, while the other species were sampled in a garden within the city. In Sirsa, samples were from the Central Cotton Research Institute, in Kumiharwala in and adjacent to cotton fields, and in Sriganganagar from the Agriculture Research Station. Samples were stored for 1-2 months at $4^{\circ} \mathrm{C}$ before being shipped by courier to Ca'Tron.

\section{DNA extraction}

The DNA was extracted using a modified version of the procedure described in Doyle and Doyle (1987) [12]. $100 \mathrm{mg}$ of leaf tissue per sample were used for each extraction. The CTAB extraction solution was prepared adding 2.5\% PVP-40 and using $2 \mathrm{M} \mathrm{NaCl}$ and $25 \mathrm{mM}$ EDTA. After the addition of isopropanol, the solution was centrifuges at 10,000g for $15 \mathrm{~min}$ and the pellet washed with $70 \%$ ethanol. The extracted nucleic acids were respuspended in water and left at $4^{\circ} \mathrm{C}$ overnight. The following day, the DNA was re-extracted using one volume of cold $\left(4^{\circ} \mathrm{C}\right) 1: 1$ phenol (pH 8.0)/chloroform, in order to get a higher purity. Its quantity and quality were measured by fluorometry. Isolate code, host, and location of all samples analyzed in this study are shown in Table 1. 


\section{Rolling circle amplification (RCA) and cloning}

The GE Healthcare Illustra ${ }^{\mathrm{TM}}$ TempliPhi ${ }^{\mathrm{TM}} 500$ Amplification Kit was used, using $20 \mathrm{ng}$ of total nucleic acid extraction. The amplified samples were digested by restriction endonucleases (REs) and separated by electrophoresis on a $1.2 \%$ agarose gel in TAE. The choice of RE depended on the circular DNA of interest, with a preference for a RE recognizing a single conserved sequence in related viral sequences found in the databases. The REs of choice therefore were $\mathrm{BamHI}, \mathrm{NcoI}$ and SalI for the virus and AvaII for betasatellite, respectively. RCA digestion products were extracted and cloned into an appropriately RE-cut plasmid (either pBluescript SKII (Stratagene, La Jolla, CA) or pGEM-T Easy (Promega, Madison, WI)) using standard cloning procedures. Escherichia coli (DH5 $\alpha$ ) cells were then transformed by electroporation and plasmids extracted from resultant colonies.

\section{PCR}

Two primer pairs used were designed based on Clustal alignments (Vector NTI Advance ${ }^{\mathrm{TM}} 9$ package (Invitrogen, Carlsbad, CA)) using available database begomoviral sequences and betasatellite associated sequences. For DNA-A, PCR was carried out with degenerate primers 302 (5'-TGTGARGGYCCWTGYAARGTYCA-3') and 424 (5'CARRTMMRRTTCAAYHACAACMTVMGGA-3') to produce an amplicon of $\sim 827$ bp. For betasatellite, PCR was carried out with primers 419 (5'-CTACCCTCCCAGGGGTACACA-3') and 420 (5'-CACGTGTTGTCATGTTGGCTT-3') to produce an amplicon of 614 bp. Both PCR products were cleaned and sequenced.

\section{Computer software}

All sequences obtained were initially analyzed using the Vector NTI Advance ${ }^{\mathrm{TM}} 9$ package. All phylograms were produced using PAUP* 4.0 [39] after selecting for the best nucleotide substitution method with jMODELTEST [32]. The software RDP3.27 [26] was used to analyze and detect recombination signals from DNA alignments implementing seven different methods. BLAST algorithms were used to search for sequence similarity in the GenBank (http://blast.ncbi.nlm.nih.gov/Blast.cgi) and in the EBI databases (http://www.ebi.ac.uk/Tools/blast/). The algorithm of the NCBI Pairwise Sequence Comparison project (PASC) was used to classify the sequences taxonomically on the basis of sequence similarity [5].

\section{Results}

\section{RCA-RFLP}

RCA products were digested with AvaII, BamHI, NcoI, or SalI producing bands of different sizes (Full data set shown in Supplemental Table 1). In 14 cotton samples, out of a total of 23, no RCA product was obtained, which could be due either to the absence of circular DNA with the corresponding restriction site(s), or to the presence of contaminants that inhibited the formation of RCA products. Further RCA trials with diluted templates and repurified samples failed to generate restriction products (results not shown).

\section{PCR}

A PCR was considered positive if it yielded a detectable fragment of the expected size; in many cases, less intense fragments of larger and smaller sizes were also observed (results not shown). Out of a total of 40 samples tested, 36 and 35 were positive for the helper virus and betasatellite, respectively (Table 1). Only sample DhI produced no amplicons for either type of PCR. Samples 1a, $3 \mathrm{n}$ and HS1 were positive for betasatellite, yet negative for the helper virus; since betasatellite is dependent on a helper virus, the absence of detection of the latter is more likely due to a technical problem, rather than to the absence of the virus. Several samples (7, 10b, Cgc and RR1) were positive for the virus and negative for betasatellite, which could be absent in these samples. 


\section{Sequencing}

To confirm their viral origin, all PCR products and cloned RCA fragments were sequenced. PCR amplicons were sequenced directly: 29 from helper virus amplifications and 33 from betasatellite amplifications, of which 17 and 24 yielded readable sequences, respectively. Only a subset of sequences was readable most probably because more than one related sequence was amplified per PCR. Of the RCA-derived fragments, 15 samples yielded 44 sequences. Those shown to be fulllength virus were subsequently aligned with all the geminivirus sequences in the database using the PASC algorithm [5] to determine to which viral species they belong. The main characteristics of all the sequences are shown in Table 2.

\section{Phylogenetic analyses of the helper virus}

Because of frequent observation of recombinants in begomoviruses, species attributions are made from full-length sequences, with $89 \%$ sequence identity as the species distinction cut-off (Fauquet et al. 2003). When a phylogenetic tree based on sequence similarity was generated using only the full-length sequences, all species were clearly distinguished (Fig. 2 and Supplemental Table 2). The most similar sequences in the databases were included to indicate species affiliation, and African cassava mosaic virus (ACMV, AF259894) was included as an outgroup. The relationship between Croton yellow vein mosaic virus (CYVMV) and Mesta yellow vein mosaic virus (MeYVMV) was further clarified by analysis of recombination sites, which clearly showed a tract of recombinant origin between nucleotide positions 450 and 1150 (Fig. 3). For virus and for betasatellite (see below), the sequences obtained by PCR and RCA from the same sample always grouped together, showing consistency in diagnosis (Figs $2 b$ and $4 a$ ).

\section{Phylogenetic analyses of satellite DNA}

Overall sequence similarity among betasatellites for the partial sequences obtained was high (Supplemental Table 4). In particular, all sequences obtained from croton, papaya, guar bean, and Tribulus terrestris (puncture vine), as well as six sequences from tolerant and one from a susceptible cotton plant (1a), were identical and correspond to that of a CLCuM betasatellite (DQ364230). The sequences analyzed could be seen to group somewhat according to the helper viruses CLCuRaV, CLCuBuV and CYVMV (Fig. 4a), although with only partial sequences any clear pattern in grouping will not be significant. For the alphasatellites three major clades can be distinguished (Fig. 4b). If, as for betasatellites, 83\% identity is used as the cutoff for distinguishing species [27], clades I and II each correspond to a species, except for FN678901 and AM711115, which have $74-75 \%$ identity with the other members of clade I. Clade II is distinct from clade I, since its members have on the order of $60 \%$ identity with clade I. One croton sample (9c-RCA-a2F) grouped with the more unusual satellite types of clade III, whose first member was described by Saunders et al (2002) from ageratum in Singapore, and more recently described members were from Oman [17], Venezuela [35] and Brazil [31]. Clade III is only distantly related to the other two clades, with inter-clade identity levels that are equivalent to those with the non-related outgroup sequence, Coconut foliar decay virus (CFDV). Clade III is also less homogeneous, since these satellites were associated with both monopartite and bipartite begomoviruses, and the level of intraclade sequence identity is below the $78 \%$ identity species cutoff. When the Rep protein of these satellites was compared with that of alphasatellites, nanoviruses and circoviruses, they clearly were on a separate branch from the three other groups [31, 35].

\section{Structural features of full-length helper virus molecules}

Genome structure analysis showed that all the virus molecules contain ORFs AV1, AV2, AC1, AC3 and either one of the two putative AC5 ORFs (Suppl. Fig. 1a). The ToLCNDV molecule extracted from bottle gourd sample 4 had an extra ORF, named AV3, which is not present in the other molecules. Only the CLCuBuV molecules found in cotton samples L2 and L4K lacked a complete AC2 ORF, which encodes the transcriptional activator protein, TrAP, and may also function as an 
RNAi suppressor. This is also the case in the CLCuBuV reference sequence (AM421522). An alignment was performed using the three sequences found in this study and the CLCuBuV sequence (GQ247893), which was the most similar sequence present in the databases. The two single mutations at positions 1487 and 1499 ( $\mathrm{C}$ to A and T to $\mathrm{G}$, corresponding to positions 1489-1501 in CLCuBuV) created two in-frame stop codons, which shorten the ORF from 405 to 105 bp and would reduce the TrAP protein to a polypeptide of 35 aa, instead of 135.

It was suspected that molecule 10c-RCA-A1-F was the product of recombination between geminiviral DNAs, a fact confirmed with the RDP 3.27 package [26] of sequence 10c-RCA-A1-F and the reference sequences of MeYVMV (FJ159262) and Bhendi yellow vein mosaic virus (BYVMV) (EU589392) (Fig. 5) Two breakpoints were detected, at nucleotide positions 1108 and 1458 (encompassing the AC3 ORF (1459-1058)), with $P$-values of seven methods ranging from $4.39 \times 10^{-04}$ to $1.58 \times 10^{-11}$ (Supplemental Table 6). Using the BLAST algorithm a PASC value of 87.4\% was obtained for 10c-RCA-A1-F with the nearest sequence, MeYVMV, therefore suggesting that in fact this virus molecule might be a putative new species.

\section{Structural features of full-length satellite DNA sequences}

Eight full-length alphasatellite-related sequences from six samples were found using RCA (Tables 1 and 2). All had the typical structure of an alphasatellite: a single ORF (coding for a replicationassociated protein) and an A-rich region immediately downstream (Suppl. Fig. 1b).

Only one full-length betasatellite sequence (L2-RCA-b1-F) was obtained in this study, and was associated with CLCuBuV (Suppl. Fig. 1c). However, another circular betasatellite sequence (LG-RCA-b1-r) was only slightly shorter than L2-RCA-b1-F (1228 nts, instead of $1354 \mathrm{nts}$ ), and in it the region immediately upstream of the beta C1 ORF, located between nucleotide 507 and nucleotide 874, was replaced by an inverted repeat of 242 nucleotides (nts 263 to 505), which would encode most of the $\beta C 1$ ORF (Suppl. Fig. 1d). The resultant molecule has an entire beta C1 ORF on the complementary sense and an almost completely duplicated beta C1 ORF on the virion sense. This is similar to another betasatellite found in the database (Acc. No. EU384591.

In order to determine whether 9c-RCA-a2 was a full-length circular DNA, PCR (not shown) with primers binding in the region flanking the BamHI restriction site was performed. The PCR confirmed that the molecule was circular, but that it was 24 nucleotides longer than the cloned RCA molecule, due to the presence of an additional BamHI site. Despite the low similarity to other alphasatellites, this molecule shared the same genomic structure (a single ORF in the virion sense and an A-rich region immediately downstream) and the same nona-nucleotide sequence at the putative origin of replication (TAGTATT^AC) as other alphasatellites.

\section{Defective virus and satellite DNA molecules}

RCA produced several DNA molecules of both alphasatellite (9S1-RCA-a4-D; 9S1-RCAa5-D) and helper virus (10a1-RCA-A2-D; 10a1-RCA-A3-D; L2-RCA-A2-D; LG-RCA-A3-D) that, although the origin of replication was intact, contained a deletion in the central region. PCR using specific primers flanking the putative deleted region confirmed that the deletions were not simply artefacts (not shown). The organization of the defective virus molecules was similar, since they lacked the central region, with only certain ORFs intact, namely AV2, AV1, AC1, AC4, AC5 (Suppl. Fig. 1a). The sizes of some of the molecules were about one quarter (LG-RCA-A3-D), one third (L2-RCA-A2-D) or half (alphasatellites: 9S1-RCA-a4-D, 9S1-RCA-a5-D) of that of a fulllength molecule. Molecule L2-RCA-A2-D had two deletions (confirmed also by PCR) (at positions 195-1811 and 2023-2307), and as a result, only three ORFs, a partial AV2 sequence, a partial AC1 sequence and an ORF composed of the first part of AC4 and the end of AC1.

There were three RCA-derived molecules that were helper virus recombinants, either with sequences of unknown origin (10a1-RCA-A6-r), or with viral sequences of anotherorigin (L2-RCAA3-r, 9S1-RCA-a6-r). Molecule L2-RCA-A3-r (Suppl. Fig. 1e) was a recombinant between virus and a betasatellite, the latter being an insert in the central region. Molecule 9S1-RCA-a6-r (Suppl. 
Fig. 1f), which we initially classified as an alphasatellite, is more correctly a recombinant virus sequence containing the origins of replication of both helper virus and alphasatellite.

\section{Virus-host specificity}

In general, there was a correlation between the virus species and the host species. CYVMV was detected only in croton and guar bean; the cotton leaf curl viruses were only observed in cotton; and the tomato leaf curl viruses were only in bottle gourd, cucumber, papaya and congress grass. Clerodendrum golden mosaic China virus is a bipartite geminivirus, the virus sequence of which was found only in the clerodendrum sample. Plants infected with more than one virus species were rare, the exceptions being okra samples 10a1 and 10c which were infected with MeYVMV and BYVMV, and croton sample 9c which was infected with CYVMV and BYVMV (and Tomato leaf curl Patna virus (ToLCPaV) as a partial sequence). It is of note that in one cotton sample, 9S1, three full-length alphasatellite sequences were detected, along with two defective sequences and a recombinant molecule between an alphasatellite and a CLCuV.

\section{Discussion}

The principal findings of this study are the following: 1) confirmation that CLCuBuV and associated betasatellite are present in Indian cotton fields, 2) none of the geminiviruses infecting cotton were found associated with nearby crops or weeds, 3) associated betasatellites were hostpromiscuous, 4) the identification of a novel alphasatellite-related molecule. Additionally, we have demonstrated that RCA and PCR are complementary techniques (in particular when in this case RCA yields - most likely because of reduced sample quality - false negatives), and together can form a robust approach to circular DNA virus and satellite characterization.

The presence of CLCuBuV molecules signifies that this species has spread from its origin in Pakistan [4]. [24]; many of the plants from Kumiharwala and Sriganganagar, the sites closest to Pakistan, also harbor it. To our knowledge this is the first published report of the presence of this virus in India.

Sequence analysis of the CLCuBuV isolates highlights a notable truncation in the C2 gene, a homologue of the TrAP protein of bipartite begomoviruses, caused by the presence of an opal and amber stop codon. The C2 protein is multifunctional, up-regulating virion-sense gene transcription and host gene expression, while down-regulating suppression of gene silencing and the hypersensitive response [13-14, 38, 41]. More specifically, cell death elicited by the AV2 protein was shown to be suppressed by the AC2 protein [29]. The persistence of a virus with a truncated form of a gene that is clearly implicated in the modulation of plant antiviral defences is surprising, although the potential leakiness of the opal and amber stop codons [37], may point to a possible mode of gene regulation rather than complete truncation. The C-terminus functions as a transcriptional activator [10], which may or may not be functionally linked to suppression of gene silencing [41]. It may be significant that the nuclear localization signal ${ }^{28} \mathrm{RRRR}^{31}$ is just upstream of the stop codons, signifying a possible retention of gene regulatory function, although one of the residues (30) in two of isolates is a lysine instead of a arginine, a change that might affect disease phenotype [10]. Identification of a truncated TrAP gene in Pakistani CLCuV isolates has also been recently reported [4]. In that study, they showed that $\mathrm{CLCuBuV}$, aside from being the only virus present in resistant cotton, possessed a C2 gene containing three mutations; facts that point possibly to more prolonged selection in favor of this virus.

One of the epidemiological aspects of CLCuD that would be useful to address is how the virus survives after cropping; it is not seed-borne and is known to have malvaceous and solanaeous hosts, including ageratum, cotton, hibiscus, okra, tobacco, and tomato. Other sources could also include weeds and cotton rattoons [7]. Although there was a limited number of cultivated crops and weeds examined in this study in none did we find viruses similar to those found in cotton, therefore suggesting a degree of host specialization, although it has been shown that the same species of begomoviruses that naturally infect okra are also found in cotton [43]. Similarly, in Burkina Faso, 
Okra leaf curl diseased plants were infected by cotton leaf curl Gezira virus [40], while yellow vein disease of Digera arvensis, a common weed, was found associated with CLCuRaV [28]. Thus, while our results do not exclude the possibility transfer of CLCuV between hosts, they do not provide evidence that it is the norm.

In contrast, the picture obtained from the betasatellites points to a less selective, more promiscuous distribution. These findings are in line with previous work where seven begomoviruses associated with CLCuD have been found associated with a single betasatellite [8, 23], and Cotton leaf curl Multan betasatellite (CLCuMB) was found with yellow vein mosaic disease in mesta [11]. In our study, sequences of CLCuV-associated betasatellite were found in croton, guar bean, papaya and Tribulus.

All the defective molecules identified here are similar to those described previously; they contain the intergenic region and part of the AC1 gene, and are accompanied by full-length helper virus [21]. These molecules may attenuate symptoms, as has been shown for East African cassava mosaic Cameroon virus [6], and they could also serve as templates for recombination allowing for rapid repair of degenerate viral sequences or the creation of novel combinations of viral genes. Of the 12 full-length virus molecules sequenced in this work, only one was a novel recombinant, and its structure was the same as that of other begomoviruses described [20].

All the full-length molecules characterized here were generated by RCA, which is proving to be an invaluable tool for studying geminiviruses [15]. Our failure to obtain clonable amounts of amplified DNA from specific cotton samples by RCA, while confirming the presence of such molecules by PCR, highlights the usefulness of applying both methods for virus characterization in particular when because of less than optimal sample quality RCA yields false negatives. Cotton is a difficult material for extraction of nucleic acids, and this problem might have limited the efficiency of RCA in our lab. With RCA-negative samples, even when the extracted nucleic acids were diluted to avoid the possible harmful effects of contaminating substances [15], the RCA experiments remained unsuccessful. Our results clearly show that, at least for detection purposes, a good set of PCR primers is sufficient although in most cases the partial sequence produced cannot be used to conclusively identify the DNA component.

The results of this study have unequivocally demonstrated the presence of the resistancebreaking CLCuBuV in India, a fact that can be in part explained by the virus' initial rapid spread from its source in Pakistan, assisted by wind conditions that would favor the movement of Bemisia tabaci, and the nature of geography of the border region. Recent work in breeding has so far not provided a complete solution to this threat to cotton cultivation [2], therefore highlighting the urgent need for a more concerted effort to understand the ecology of CLCuD-associated viruses and their control.

\section{Acknowledgements}

Many thanks to Dr. Dilip Mongia, CICR Sirsa, Prof. Narayan Rishi, CCS Agriculture University, Hissar for assistance in the field, and to Mirco Boem, Laura Chiappetta, Slavica Matic, Marco Morroni, Arianna Friscina and Amit Bhardwaj for technical support and sound advice. This work was funded in part by Fondazione Cassamarca. Financial support of ICGEB is acknowledged.

\section{References}

1. Ahuja SL, Monga D, Dhayal LS (2007) Genetics of resistance to cotton leaf curl disease in Gossypium hirsutum L. under field conditions. J Hered 98:79-83

2. Akhtar KP, Jamil FF, Haq MA, Khan IA (2008) Comparison of resistance to cotton leaf curl disease (Multan/Burewala) in Gossypium hirsutum L. varieties and breeding lines. J Phytopathology 156:352-357

3. Ali M (1997) Breeding of cotton varieties for resistance to cotton leaf curl virus. Pakistan J Phytopathol 9:1-7 
4. Amrao L, Amin I, Shahid MS, Briddon RW, Mansoor S (2010) Cotton leaf curl disease in resistant cotton is associated with a single begomovirus that lacks an intact transcriptional activator protein. Virus Res

5. Bao Y, Kapustin Y, Tatusova T (2008) Virus Classification by Pairwise Sequence Comparison (PASC). . In: Mahy BWJ, Van Regenmortel MHV (eds) Encyclopedia of Virology. Elsevier, Oxford, pp 342-348.

6. Behjatnia SA, Dry IB, Rezaian MA (2007) Characterization and transient replication of tomato leaf curl virus defective DNAs. Arch Virol 152:1127-1138

7. Briddon RW, Markham PG (2000) Cotton leaf curl virus disease. Virus Res 71:151-159

8. Briddon RW, Mansoor S, Bedford ID, Pinner MS, Saunders K, Stanley J, Zafar Y, Malik KA, Markham PG (2001) Identification of dna components required for induction of cotton leaf curl disease. Virology 285:234-243

9. Briddon RW, Stanley J (2006) Subviral agents associated with plant single-stranded DNA viruses. Virology 344:198-210

10. Chowda-Reddy RV, Dong W, Felton C, Ryman D, Ballard K, Fondong VN (2009) Characterization of the cassava geminivirus transcription activation protein putative nuclear localization signal. Virus Res 145:270-278

11. Das S, Roy A, Ghosh R, Paul S, Acharyya S, Ghosh SK (2008) Sequence variability and phylogenetic relationship of betasatellite isolates associated with yellow vein mosaic disease of mesta in India. Virus Genes 37:414-424

12. Doyle JJ, Doyle JL (1987) A rapid DNA isolation method for small quantities of fresh tissues. Phytochemical Bulletin of the Botanical Society of America 19:11-15

13. Dry I, Krake L, Mullineaux P, Rezaian A (2000) Regulation of tomato leaf curl viral gene expression in host tissues. Mol Plant Microbe Interact 13:529-537

14. Gopal P, Pravin Kumar P, Sinilal B, Jose J, Kasin Yadunandam A, Usha R (2007) Differential roles of $\mathrm{C} 4$ and betaC1 in mediating suppression of post-transcriptional gene silencing: evidence for transactivation by the C2 of Bhendi yellow vein mosaic virus, a monopartite begomovirus. Virus Res 123:9-18

15. Haible D, Kober S, Jeske H (2006) Rolling circle amplification revolutionizes diagnosis and genomics of geminiviruses. J Virol Methods 135:9-16

16. Hussain T, Mahmood T (1988) A note on leaf curl disease of cotton. Pakistan Cottons 32(4):248-251

17. Idris AM, Shahid MS, Briddon RW, Khan AJ, Zhu JK, Brown JK (2011) An unusual alphasatellite associated with monopartite begomoviruses attenuates symptoms and reduces betasatellite accumulation. J Gen Virol 92:706-717

18. Kirthi N, Priyadarshini CG, Sharma P, Maiya SP, Hemalatha V, Sivaraman P, Dhawan P, Rishi N, Savithri HS (2004) Genetic variability of begomoviruses associated with cotton leaf curl disease originating from India. Arch Virol 149:2047-2057

19. Kumar A, Kumar J, Khan JA (2010) Sequence characterization of cotton leaf curl virus from Rajasthan: phylogenetic relationship with other members of geminiviruses and detection of recombination. Virus Genes 40:282-289

20. Lefeuvre P, Martin DP, Hoareau M, Naze F, Delatte H, Thierry M, Varsani A, Becker N, Reynaud B, Lett JM (2007) Begomovirus 'melting pot' in the south-west Indian Ocean islands: molecular diversity and evolution through recombination. J Gen Virol 88:3458-3468

21. Liu Y, Robinson DJ, Harrison BD (1998) Defective forms of cotton leaf curl virus DNA-A that have different combinations of sequence deletion, duplication, inversion and rearrangement. J Gen Virol 79 ( Pt 6):1501-1508

22. Mansoor S, Khan SH, Bashir A, Saeed M, Zafar Y, Malik KA, Briddon R, Stanley J, Markham PG (1999) Identification of a novel circular single-stranded DNA associated with cotton leaf curl disease in Pakistan. Virology 259:190-199 
23. Mansoor S, Briddon RW, Bull SE, Bedford ID, Bashir A, Hussain M, Saeed M, Zafar Y, Malik KA, Fauquet C, Markham PG (2003) Cotton leaf curl disease is associated with multiple monopartite begomoviruses supported by single DNA beta. Arch Virol 148:1969-1986

24. Mansoor S, Amin I, Hussain M, Zafar Y, Briddon RW (2006) Engineering novel traits in plants through RNA interference. Trends Plant Sci 11:559-565

25. Mansoor S, Zafar Y, Briddon RW (2006) Geminivirus disease complexes: the threat is spreading. Trends Plant Sci 11:209-212

26. Martin DP, Williamson C, Posada D (2005) RDP2: recombination detection and analysis from sequence alignments. Bioinformatics 21:260-262

27. Mubin M, Briddon RW, Mansoor S (2009) Complete nucleotide sequence of chili leaf curl virus and its associated satellites naturally infecting potato in Pakistan. Arch Virol 154:365368

28. Mubin M, Briddon RW, Mansoor S (2009) Diverse and recombinant DNA betasatellites are associated with a begomovirus disease complex of Digera arvensis, a weed host. Virus Res 142:208-212

29. Mubin M, Amin I, Amrao L, Briddon RW, Mansoor S (2010) The hypersensitive response induced by the V2 protein of a monopartite begomovirus is countered by the C2 protein. Mol Plant Pathol 11:245-254

30. Nawaz-ul-Rehman MS, Fauquet CM (2009) Evolution of geminiviruses and their satellites. FEBS Lett 583:1825-1832

31. Paprotka T, Metzler V, Jeske H (2010) The first DNA 1-like alpha satellites in association with New World begomoviruses in natural infections. Virology 404:148-157

32. Posada D (2008) jModelTest: phylogenetic model averaging. Mol Biol Evol 25:1253-1256

33. Qazi J, Amin I, Mansoor S, Iqbal MJ, Briddon RW (2007) Contribution of the satellite encoded gene betaC1 to cotton leaf curl disease symptoms. Virus Res 128:135-139

34. Rojas MR, Hagen C, Lucas WJ, Gilbertson RL (2005) Exploiting chinks in the plant's armor: evolution and emergence of geminiviruses. Annu Rev Phytopathol 43:361-394

35. Romay G, Chirinos D, Geraud-Pouey F, Desbiez C (2010) Association of an atypical alphasatellite with a bipartite New World begomovirus. Arch Virol 155:1843-1847

36. Saunders K, Bedford ID, Briddon RW, Markham PG, Wong SM, Stanley J (2000) A unique virus complex causes Ageratum yellow vein disease. Proc Natl Acad Sci U S A 97:68906895

37. Skuzeski JM, Nichols LM, Gesteland RF, Atkins JF (1991) The signal for a leaky UAG stop codon in several plant viruses includes the two downstream codons. J Mol Biol 218:365-373

38. Sunter G, Bisaro DM (1992) Transactivation of geminivirus AR1 and BR1 gene expression by the viral AL2 gene product occurs at the level of transcription. Plant Cell 4:1321-1331

39. Swofford DL (1993) Paup - a Computer-Program for Phylogenetic Inference Using Maximum Parsimony. J Gen Physiol 102:A9-A9

40. Tiendrebeogo F, Lefeuvre P, Hoareau M, Villemot J, Konate G, Traore AS, Barro N, Traore VS, Reynaud B, Traore O, Lett JM (2010) Molecular diversity of cotton leaf curl Gezira virus isolates and their satellite DNAs associated with okra leaf curl disease in Burkina Faso. Virol J 7:48

41. Trinks D, Rajeswaran R, Shivaprasad PV, Akbergenov R, Oakeley EJ, Veluthambi K, Hohn T, Pooggin MM (2005) Suppression of RNA silencing by a geminivirus nuclear protein, AC2, correlates with transactivation of host genes. J Virol 79:2517-2527

42. Wu P-J, Zhou X-P (2005) Interaction between a Nanovirus-like Component and the Tobacco Curly Shoot Virus/Satellite Complex. Acta Biochimica et Biophysica Sinica 37:25-31

43. Zhou X, Liu Y, Robinson DJ, Harrison BD (1998) Four DNA-A variants among Pakistani isolates of cotton leaf curl virus and their affinities to DNA-A of geminivirus isolates from okra. J Gen Virol 79 ( Pt 4):915-923 


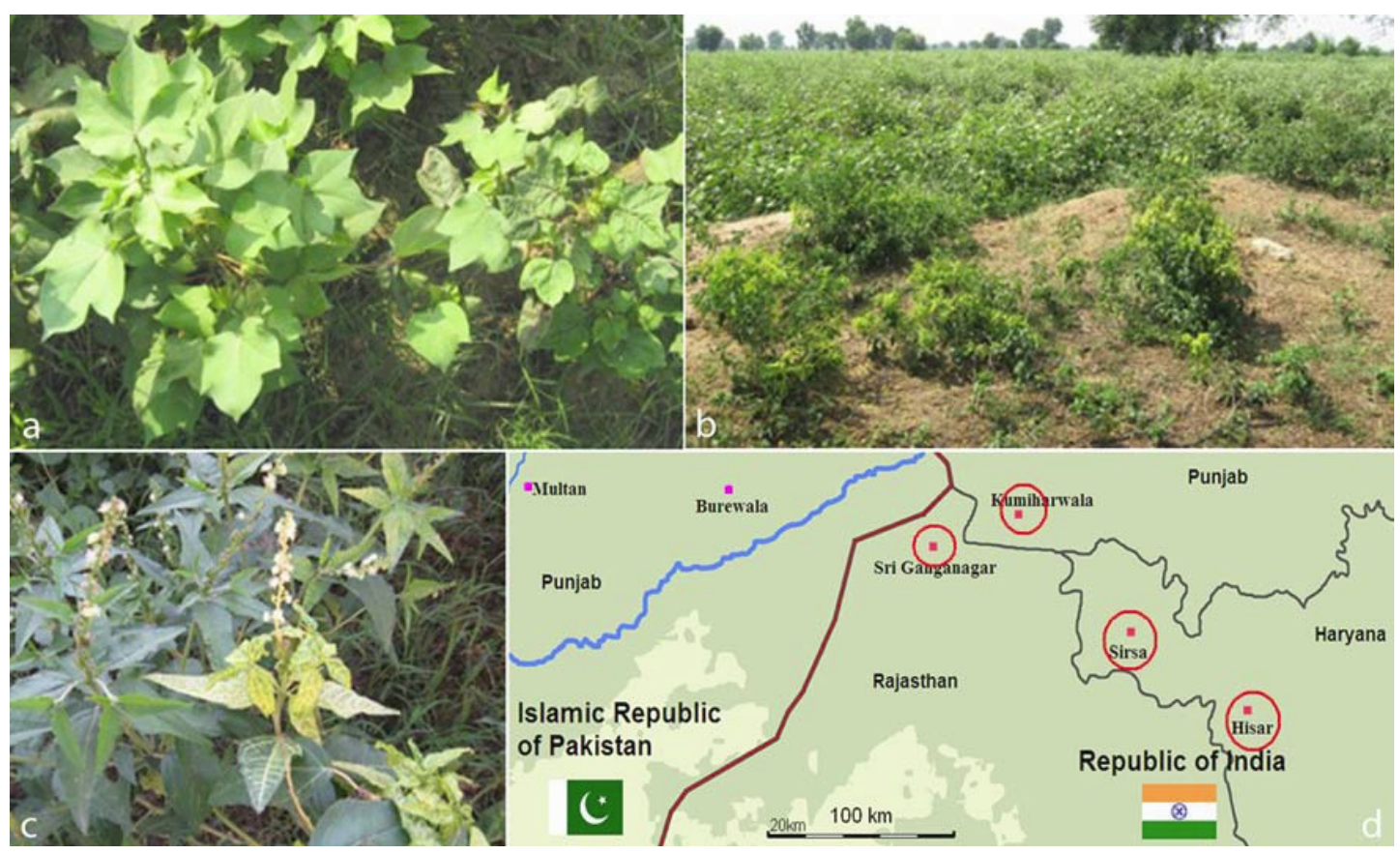

Fig. 1. Plant symptoms and sampling locations. Cotton and croton plants in a field in Northwestern India. (a) a healthy cotton plant (left) and a cotton plant affected by leaf curl disease (right). (b) a typical Northwestern Indian cotton field environment with infected croton (foreground) growing next to a cotton field. (c) a healthy croton plant (left) and a croton plant affected by yellow vein mosaic disease (right). (d) map of the sampling region. The cities where the samples were collected are shown along with the cities of Multan (Pakistan), where CLCuD was originally detected, and Burewala from which currently the most dominant species takes its name. 
Fig. 2. Phylogenetic trees of helper virus sequences (a) full-length sequences and (b) 492-498 nts in the AV1 ORF. Trees were obtained obtained using PAUP*4.0 (neighbor-joining) (Swofford, 1993) after selecting for the best nucleotide substitution model with jModeltest (Posada, 2008). Bootstrap values were calculated from 100 iterations. Branches with bootstrap values less than 70 were collapsed. Bar: number of substitutions per nucleotide. Virus species in bold. ACMV was used as outgroup. TLCuNDV - Tomato leaf curl New Delhi virus, CGMV Clerodendrum golden mosaic China virus, ToLCKV - Tomato leaf curl Karnataka virus

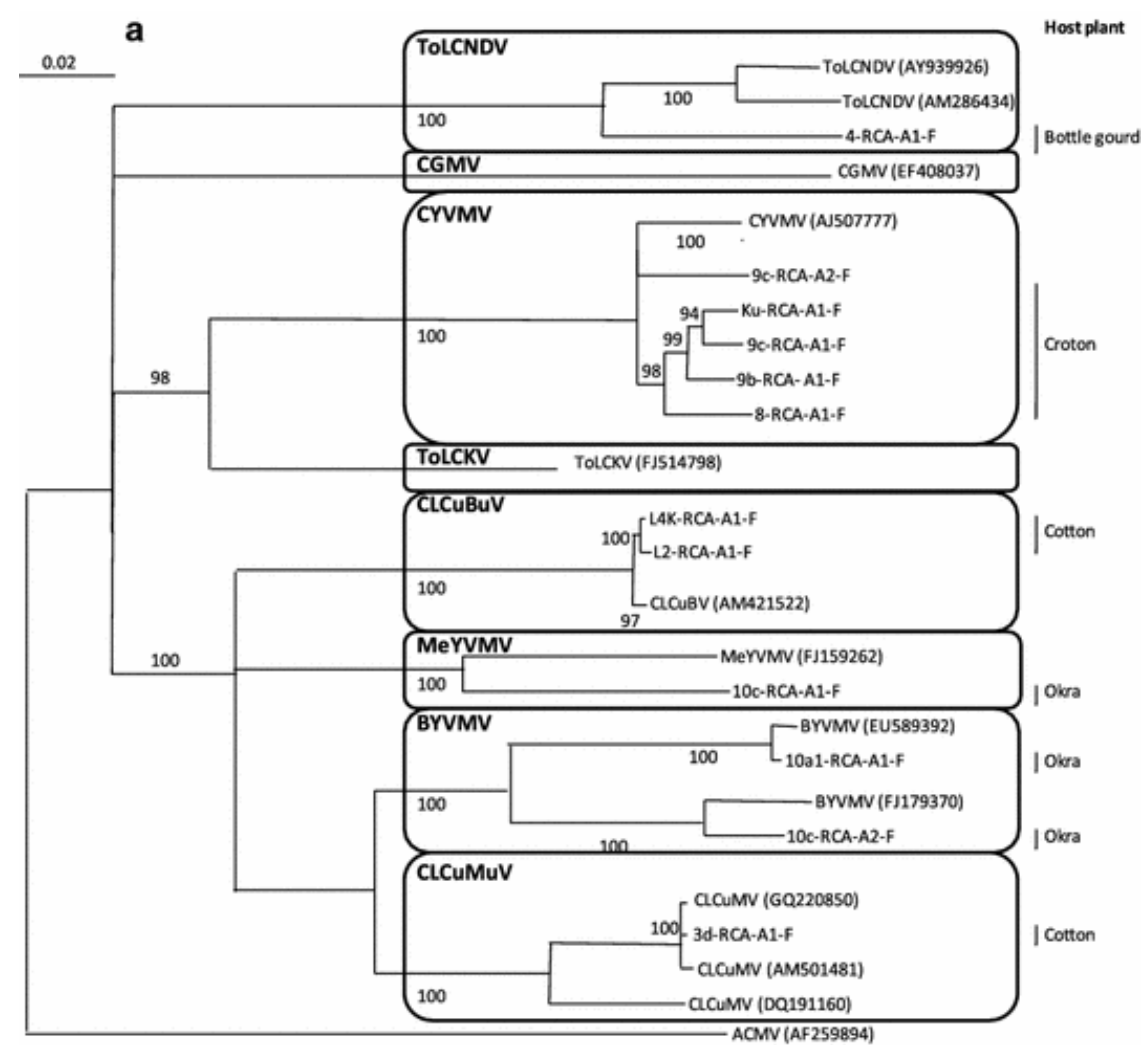

b

Host plant

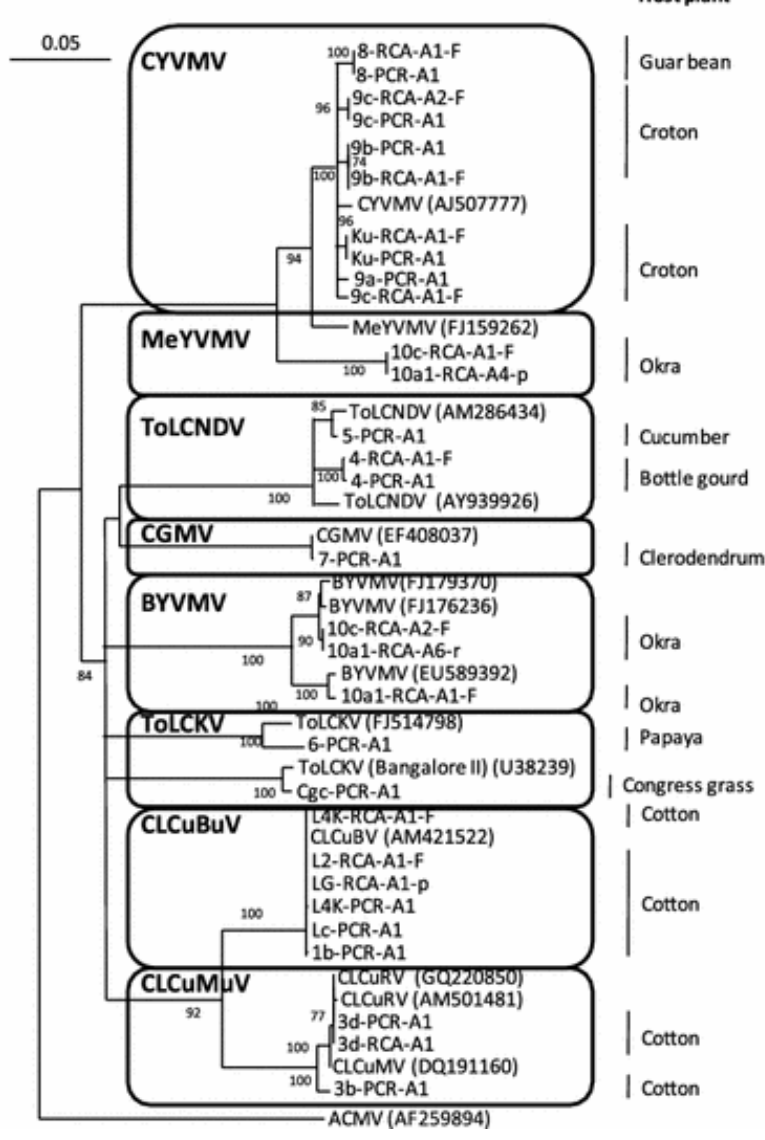




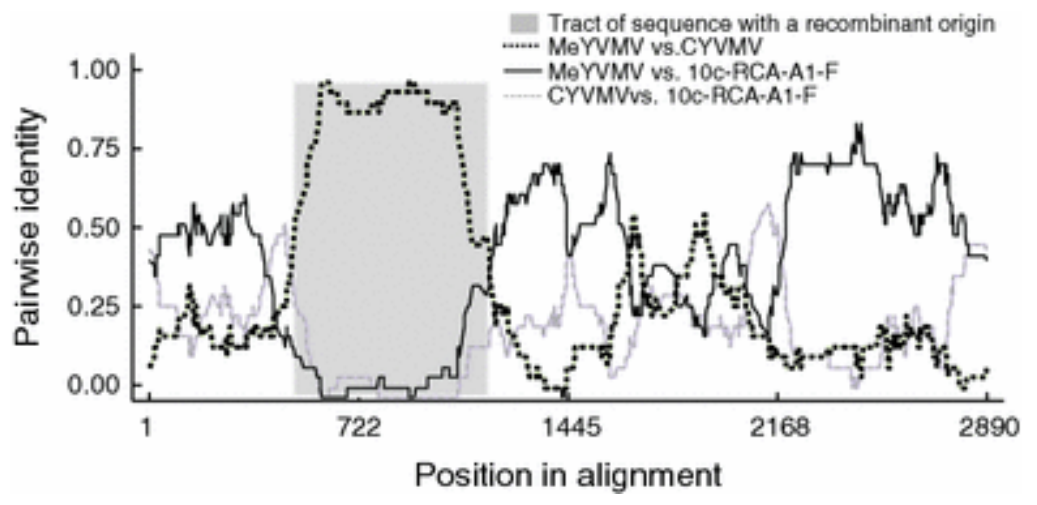

Fig. 3. Recombination involving MeYVMV and CYVMV. Pairwise identities (y-axis) between MeYVMV, CYVMV and molecule 10c-RCA-A1-F as determined by the RDP3 program (Martin et al., 2005). Nucleotide position in the genome shown on $\mathrm{x}$-axis. 
Fig. 4. Phylogenetic trees of satellite DNA sequences. (a) betasatellite sequences (274293 nts including the A-rich region), and (b) full-length alphasatellite sequences. The trees were obtained using PAUP*4.0 (neighbor-joining) [39] after selecting for the best nucleotide substitution model with jModeltest [32]. Bootstrap values were calculated from 100 iterations. Branches with bootstrap values less than 70 were collapsed. Bar: number of substitutions per nucleotide. HYVMVA and CFDV were used as outgroups in (a) and (b), respectively. Nd- not defined. AYVV- Ageratum yellow vein virus, MeCMV melon chlorotic mosaic virus, GdSA - Gossypium davidsonii symptomless alphasatellite, TbCSV - Tobacco curly shoot virus.

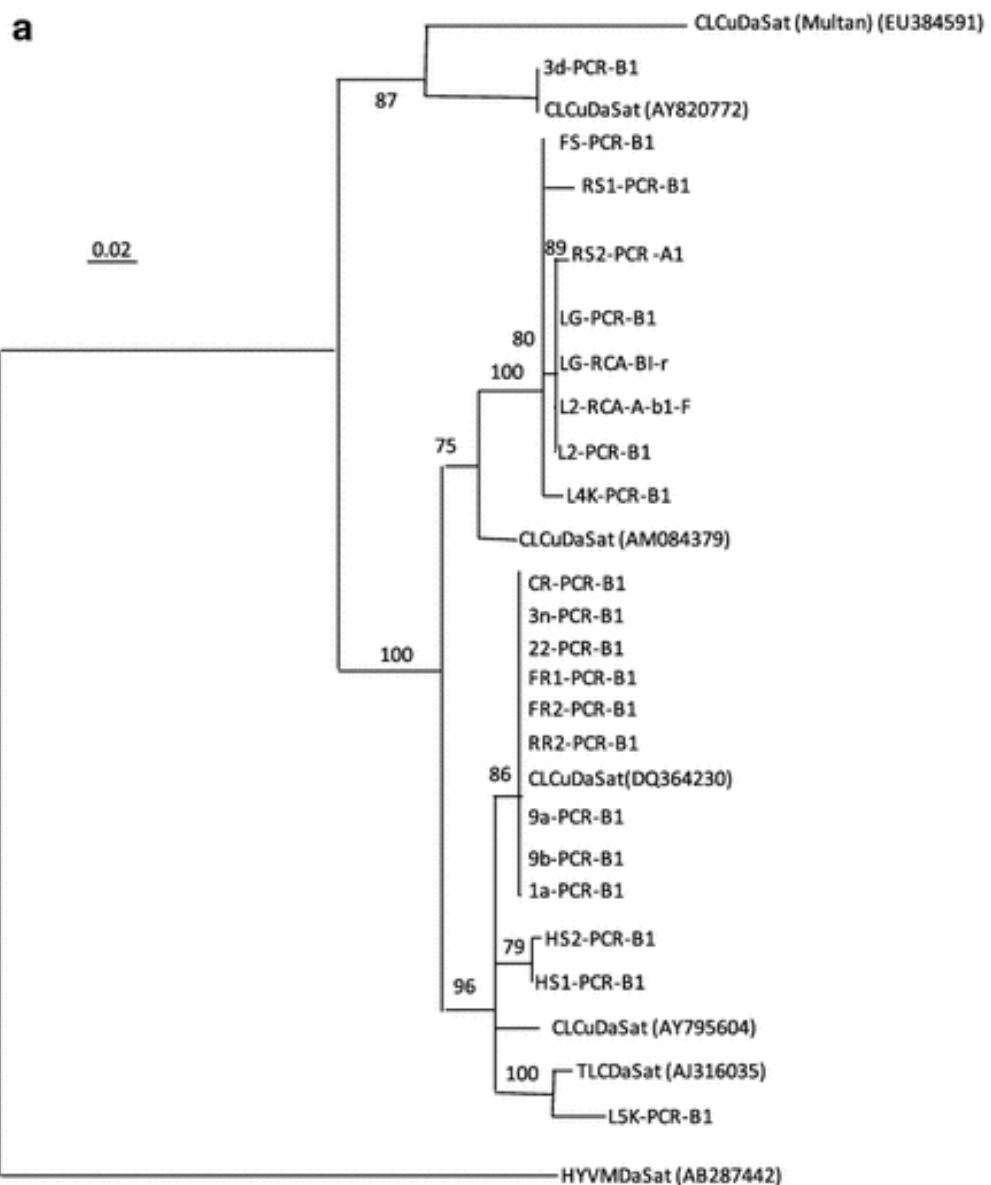

Helper virus

CLCuRav

cacubuv

nd

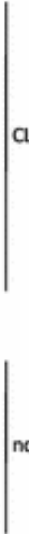

CrVMV/ToLCPaV CrVMV

nd

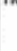

nd

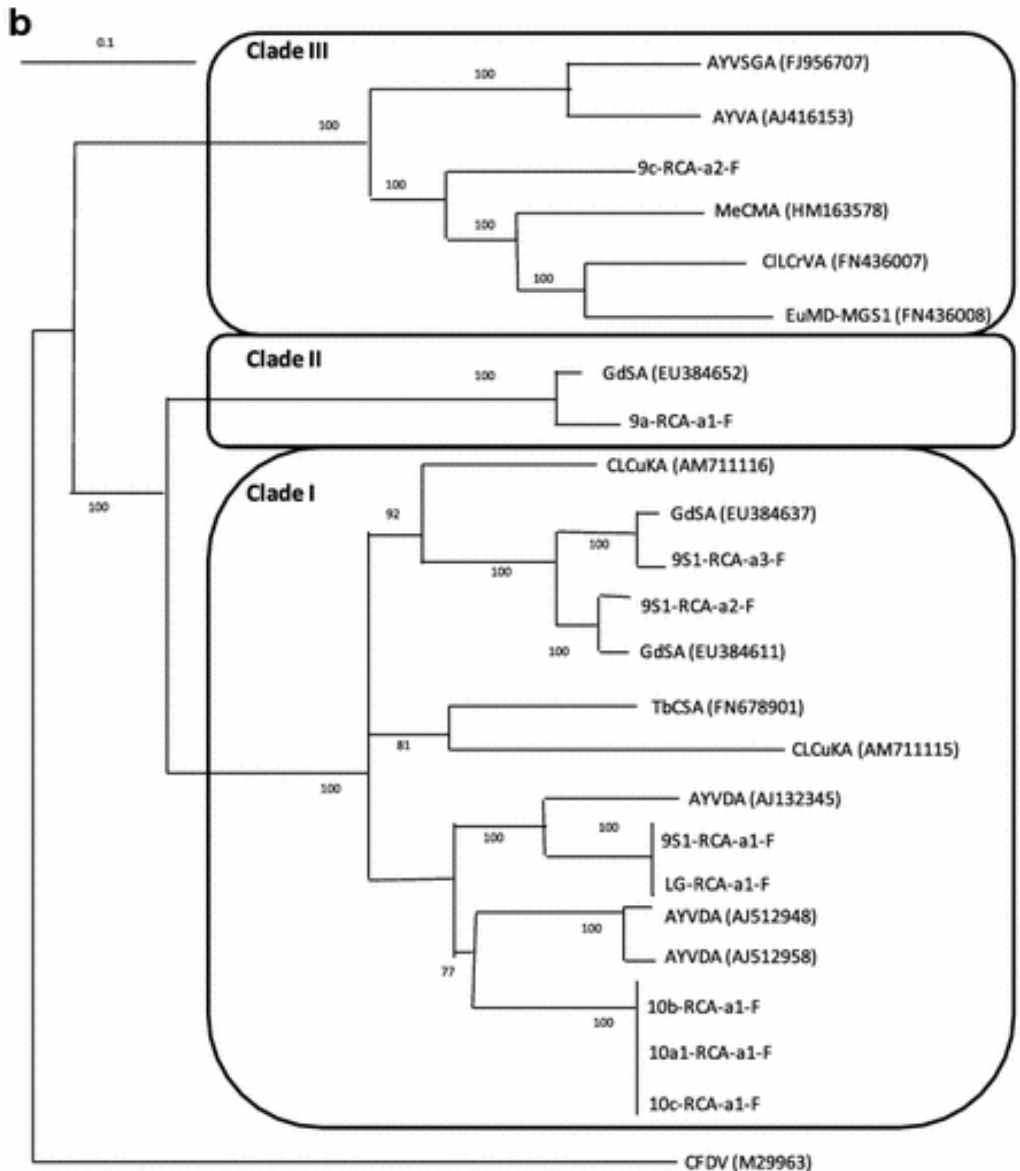

Helper virus

Truc

Arrv

CrVMV+BrVMV

Mecmiv

GdSV

CYVMV + ToLCPaV

cLCukov

GdSV

cacubuv

cacueuv

GdSV

TbCSV

cacakov

Arv

cacubuv

cLousu

ArvV

AYVV

nd

MervMV+BrVMV

Mervmv+ BYvMV 


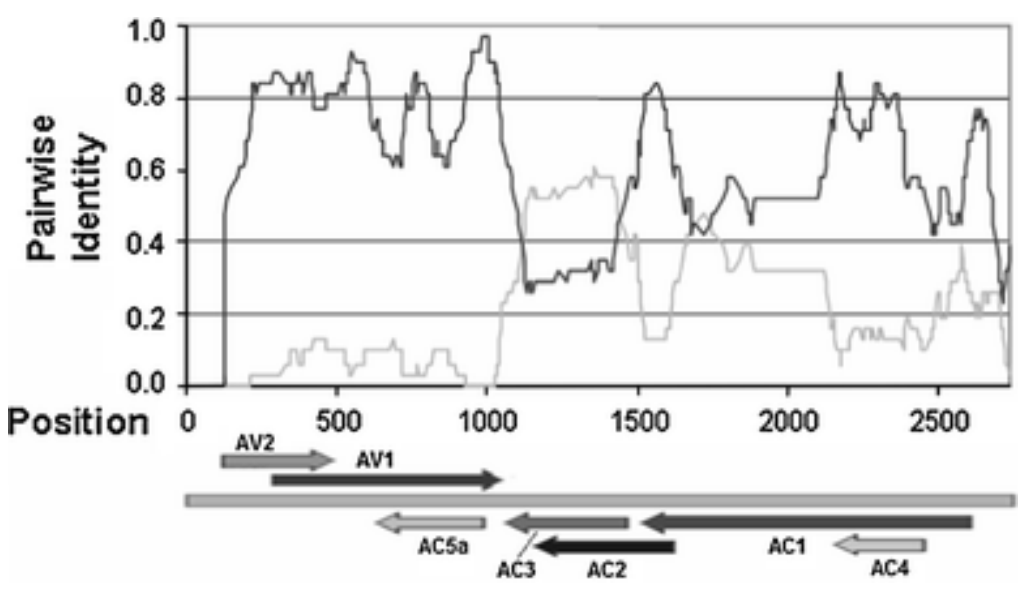

Fig. 5. Pairwise identities (y-axis) between molecule 10c-RCA-A1-F and EU589392 (light grey) and between 10c-RCA-A1-F and FJ159262 (dark grey) in relation to nucleotide position (x-axis) in the genome as determined by the RDP3 program [26]. Below the graph, the genome organization of 10c-RCA-A1-F is displayed with the direction of each ORF indicated. 
Table 1. Symptoms and presence/absence of geminiviral DNAs in samples analysed

\begin{tabular}{|c|c|c|c|c|c|c|}
\hline \multirow[t]{2}{*}{ Sample } & \multirow[t]{2}{*}{ Location } & \multirow[t]{2}{*}{ Host species } & \multirow[t]{2}{*}{ Symptoms } & \multicolumn{2}{|c|}{ PCR } & \multirow[t]{2}{*}{ RCA } \\
\hline & & & & $A$ & $\beta$ & \\
\hline $9 a$ & Hisar & Croton (Croton sp.) & + & + & + & $\mathrm{A}, \alpha$ \\
\hline $9 b$ & Hisar & Croton & + & + & + & A \\
\hline $9 c$ & Hisar & Croton & + & + & $+/-$ & $\mathrm{A}, \alpha$ \\
\hline 4 & Hisar & Bottle gourd (Lagenaria siceraria) & + & + & $+/-$ & A \\
\hline 7 & Hisar & Clerodendrum (Clerodendrum sp.) & + & + & - & A, d \\
\hline $1 \mathrm{a}$ & Hisar & Cotton (Gossypium hirsutum) & + & - & + & n.a. \\
\hline $1 b$ & Hisar & Cotton & + & + & + & + \\
\hline $3 b$ & Hisar & Cotton & + & + & + & n.a. \\
\hline 3d & Hisar & Cotton & + & + & + & A \\
\hline $3 n$ & Hisar & Cotton & - & - & + & + \\
\hline 5 & Hisar & Cucumber (Cucumis sativus) & + & + & + & + \\
\hline 8 & Hisar & Guar bean (Cyamopsis tetragonoloba) & + & + & + & A \\
\hline $10 \mathrm{a}$ & Hisar & Okra (Abelmoschus esculentus) & + & + & + & A, $\alpha$ \\
\hline $10 \mathrm{~b}$ & Hisar & Okra & + & $+/-$ & - & $\alpha$ \\
\hline 10c & Hisar & Okra & + & + & + & A, $\alpha$ \\
\hline 6 & Hisar & Papaya (Carica papaya) & + & + & + & + \\
\hline HS1 & Sirsa & Cotton & + & - & $+/-$ & + \\
\hline HS2 & Sirsa & Cotton & + & $+/-$ & + & п.а. \\
\hline $\mathrm{Ku}$ & Kumiharwala & Croton & + & + & + & A \\
\hline $\mathrm{Cg}$ & Kumiharwala & Congress grass (Parthenium hysterophorus) & + & $+/-$ & + & + \\
\hline Cgc & Kumiharwala & Congress grass & - & $+/-$ & - & + \\
\hline $\mathrm{CR}$ & Kumiharwala & Cotton & - & $+/-$ & $+/-$ & n.a. \\
\hline $\mathrm{L} 2$ & Kumiharwala & Cotton & + & + & + & $A, \beta$ \\
\hline L4K & Kumiharwala & Cotton & + & + & + & A \\
\hline L5K & Kumiharwala & Cotton & + & + & + & n.a. \\
\hline Lc & Kumiharwala & Cotton & - & + & + & n.a. \\
\hline LG & Kumiharwala & Cotton & + & + & + & $A, \alpha, \beta$ \\
\hline $130(130 / 1)$ & Sriganganagar & Cotton & - & + & + & n.a. \\
\hline $22(22 / 2)$ & Sriganganagar & Cotton & - & + & + & + \\
\hline FR1 (F/861) & Sriganganagar & Cotton & - & + & + & n.a. \\
\hline FR2 (F/861) & Sriganganagar & Cotton & - & + & + & n.a. \\
\hline FS & Sriganganagar & Cotton & + & + & + & n.a. \\
\hline RR2 (RS2013) & Sriganganagar & Cotton & - & $+/-$ & + & n.a. \\
\hline RR1 (RS2013) & Sriganganagar & Cotton & - & $+/-$ & - & n.a. \\
\hline RS1 & Sriganganagar & Cotton & + & + & + & n.a. \\
\hline RS2 & Sriganganagar & Cotton & + & + & + & n.a. \\
\hline 9S1 & Sriganganagar & Cotton & + & + & + & $\alpha$ \\
\hline DhI & Sriganganagar & Digera (Digera sp.) & + & - & - & + \\
\hline Eup & Sriganganagar & Euphorbia (Euphorbia sp.) & - & + & + & n.a. \\
\hline Tri & Sriganganagar & Puncture vine (Tribulus terrestris) & - & $+/-$ & + & + \\
\hline
\end{tabular}

From left to right the columns indicate: name, location, host plant, + or - symptoms, + or - betasatellite in dotblot, DNAs detected by PCR (A, DNA-A; $\beta$, betasatellite. + - - indicates samples that were positive in some but not all tests); DNAs detected by RCA, (A, DNA-A; $\alpha$, alphasatellite; $\beta$, betasatellite; d, other molecule; +, RCA product observed, sequence not obtained; n.a., sample not amplified). Highlighted PCR or RCA products were sequenced. 


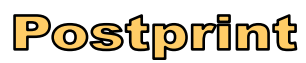

Version définitive du manuscrit publié dans / Final version of the manuscript published in : Archives of Virology, 2012, 157, 483-495. DOI: 10.1007/s00705-011-1201-y. The original publication is availalble at http://link.springer.com.

Table 2. Characteristics of viral sequences detected by PCR and RCA.

\begin{tabular}{|c|c|c|c|c|c|c|c|c|c|c|}
\hline Sample & Host plant & Sequence name & $\begin{array}{c}\text { Accession } \\
\text { number }\end{array}$ & Length & Species assignment & Closest hit & $\begin{array}{l}\text { Accession } \\
\text { number of } \\
\text { closest hit }\end{array}$ & $\begin{array}{c}\text { Coverage } \\
\text { (\%) }\end{array}$ & $\begin{array}{c}\text { Max. } \\
\text { identity } \\
(\%)\end{array}$ & $\begin{array}{c}\text { PASC } \\
(\%)\end{array}$ \\
\hline \multirow[t]{4}{*}{$9 a$} & Croton & 9a-PCR-A1 & FN645895 & 586 & n.a. & CYVMV & AJ507777.1 & 100 & 99 & \\
\hline & & 9a-RCA-A1-p & FN645896 & 1814 & n.a. & ToLCPaV & EU862323.1 & 100 & 87 & \\
\hline & & 9a-RCA-a1-F & FN658709 & 1372 & n.a. & GdSA & EU384652.1 & 88 & 91 & \\
\hline & & 9a-PCR-B1 & - & 499 & n.a. & CLCuMuB & DQ364230.1 & 100 & 100 & \\
\hline \multirow[t]{3}{*}{$9 b$} & Croton & 9b-PCR-A1 & FN645897 & 676 & n.a. & CYVMV & AJ507777.1 & 99 & 99 & \\
\hline & & 9b-RCA-A1-F & FN645898 & 2760 & CYVMV & n.a. & AJ507777.1 & & & 95.6 \\
\hline & & 9b-PCR-B1 & - & 546 & n.a. & CLCuMuB & DQ364230.1 & 100 & 99 & \\
\hline \multirow[t]{6}{*}{$9 c$} & Croton & 9c-PCR-A1 & FN645900 & 742 & n.a. & CYVMV & AJ507777.1 & 100 & 99 & \\
\hline & & 9c-RCA-A1-F & FN645901 & 2749 & CYVMV & n.a. & AJ507777.1 & 100 & 95 & \\
\hline & & 9c-RCA-A2-F & FN645902 & 2750 & CYVMV & n.a. & AJ507777.1 & 98 & 95 & \\
\hline & & 9c-RCA-A3-p & FN645903 & 1558 & n.a. & BYVMV & AJ002453.1 & 100 & 96 & \\
\hline & & 9c-RCA-a1-p & FN658710 & 1214 & n.a. & Alphasatellite & AJ512958.1 & 90 & 97 & \\
\hline & & 9c-RCA-a2-F & FN658711 & 1347 & n.a. & AYVV alphasatellite & AJ416153.1 & 31 & 67 & \\
\hline \multirow[t]{3}{*}{4} & Bottle gourd & 4-PCR-A1 & FN645904 & 675 & n.a. & ToLCNDV & AY939926.1 & 100 & 96 & \\
\hline & & 4-RCA-A1-F & FN645905 & 2737 & ToLCNDV & n.a. & AY939926.1 & & & 89.8 \\
\hline & & 4-RCA-A2-p & FN645906 & 701 & n.a. & ToLCNDV & DQ629102.1 & 100 & 96 & \\
\hline \multirow[t]{3}{*}{7} & Clerodendrum & 7-PCR-A1 & FN645907 & 739 & n.a. & ClGMV & EF408037.1 & 100 & 99 & \\
\hline & & 7-RCA-A1-p & FN645908 & 527 & n.a. & ClGMV & EF408037.1 & 100 & 99 & \\
\hline & & 7-RCA-d1-F & FN658712 & 941 & n.a. & No similarity found & & & & \\
\hline $1 \mathrm{a}$ & Cotton & 1a-PCR-B1 & - & 394 & n.a. & CLCuMuB & DQ364230.1 & 100 & 100 & \\
\hline \multirow[t]{2}{*}{$1 b$} & Cotton & 1b-PCR-A1 & FN645909 & 663 & n.a. & CLCuBuV & AM421522.1 & 100 & 99 & \\
\hline & & 1b-PCR-B1 & FN658713 & 284 & n.a. & CLCuMuB & AY795608.2 & 100 & 98 & \\
\hline $3 n$ & Cotton & 3n-PCR-B1 & - & 535 & n.a. & CLCuMuB & DQ364230.1 & 100 & 100 & \\
\hline \multirow[t]{2}{*}{$3 b$} & Cotton & 3b-PCR-A1 & FN645910 & 521 & n.a. & CLCuMuV & DQ191160.1 & 100 & 98 & \\
\hline & & 3b-PCR-B1 & FN658714 & 232 & n.a. & CLCuMuB & AY795608.2 & 100 & 98 & \\
\hline \multirow[t]{3}{*}{$3 d$} & Cotton & 3d-PCR-A1 & FN645911 & 664 & n.a. & CLCuRaV & GQ220850.1 & 100 & 100 & \\
\hline & & 3d-RCA-A1-F & FN645912 & 2753 & CLCuRaV & n.a. & AM501481.1 & & & 99.6 \\
\hline & & 3d-PCR-B1 & FN658715 & 269 & n.a. & CLCuMuB & AY820772.1 & 100 & 100 & \\
\hline 5 & Cucumber & 5-PCR-A1 & FN645913 & 655 & n.a. & ToLCNDV & AM286434.1 & 100 & 98 & \\
\hline \multirow[t]{4}{*}{8} & Guar bean & 8-PCR-A1 & FN645914 & 639 & n.a. & CYVMV & AJ507777.1 & 99 & 97 & \\
\hline & & 8-RCA-A1-F & FN645915 & 2755 & CYVMV & n.a. & AJ507777.1 & & & 94.7 \\
\hline & & 8-RCA-A2-p & FN645916 & $\begin{array}{l}754 \\
+650\end{array}$ & n.a. & ToLCNDV & AY428769.1 & 100 & 98 & \\
\hline & & 8-PCR-B1 & - & 400 & n.a. & CLCuMuB & DQ364230.1 & 100 & 100 & \\
\hline
\end{tabular}




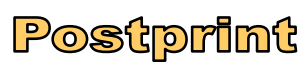

Version définitive du manuscrit publié dans / Final version of the manuscript published in : Archives of Virology, 2012, 157, 483-495. DOI: 10.1007/s00705-011-1201-y. The original publication is availalble at http://link.springer.com.

\begin{tabular}{|c|c|c|c|c|c|c|c|c|c|c|}
\hline Sample & Host plant & Sequence name & $\begin{array}{c}\text { Accession } \\
\text { number }\end{array}$ & Length & Species assignment & Closest hit & $\begin{array}{l}\text { Accession } \\
\text { number of } \\
\text { closest hit }\end{array}$ & $\begin{array}{c}\text { Coverage } \\
\text { (\%) }\end{array}$ & $\begin{array}{c}\text { Max. } \\
\text { identity } \\
(\%)\end{array}$ & $\begin{array}{c}\text { PASC } \\
(\%)\end{array}$ \\
\hline \multirow[t]{7}{*}{ 10a1 } & \multirow[t]{7}{*}{ Okra } & 10a1-RCA-A1-F & FN645917 & 2744 & BYVMV & n.a. & EU589392.1 & & & \multirow[t]{8}{*}{99.0} \\
\hline & & 10a1-RCA-A2-D & FN645918 & 2171 & n.a. & MeYVMV & FJ159262.1 & 96 & 89 & \\
\hline & & 10a1-RCA-A3-D & FN645919 & 1102 & n.a. & MeYVMV & FJ159262.1 & 94 & 87 & \\
\hline & & 10a1-RCA-A4-p & FN645920 & 1638 & n.a. & MeYVMV & FJ159262.1 & 100 & 91 & \\
\hline & & 10a1-RCA-A5-p & FN645921 & 1109 & n.a. & BYVMV & AJ002453.1 & 99 & 91 & \\
\hline & & 10a1-RCA-A6-r & - & 2666 & n.a. & BYVMV & FJ179370.1 & 88 & 100 & \\
\hline & & 10a1-RCA-a1-F & FN658716 & 1377 & n.a. & Alphasatellite & AJ512948.1 & 100 & 85 & \\
\hline $10 \mathrm{~b}$ & Okra & 10b-RCA-a1-F & FN658718 & 1377 & n.a. & Alphasatellite & AJ512948.1 & 100 & 85 & \\
\hline \multirow[t]{3}{*}{$10 \mathrm{c}$} & \multirow[t]{3}{*}{ Okra } & 10c-RCA-A1-F & FN645922 & 2742 & 'MeYVMV' & n.a. & FJ159262.1 & & & \multirow{3}{*}{$\begin{array}{l}87.4 \\
100\end{array}$} \\
\hline & & 10c-RCA-A2-F & FN645923 & 2709 & n.a. & BYVMV & FJ176236.1 & 95 & 96 & \\
\hline & & 10c-RCA-a1-F & FN658717 & 1377 & n.a. & Alphasatellite & AJ512948.1 & 100 & 85 & \\
\hline \multirow[t]{2}{*}{6} & \multirow[t]{2}{*}{ Papaya } & 6-PCR-A1 & FN645924 & 749 & n.a. & ToLCKaV & FJ514798.1 & 100 & 94 & \\
\hline & & 6-PCR-B1 & - & 542 & n.a. & CLCuMuB & DQ364230.1 & 100 & 100 & \\
\hline HS1 & Cotton & HS1-PCR-B1 & FN658720 & 515 & n.a. & CLCuMuB & AY795604.1 & 100 & 100 & \\
\hline HS2 & Cotton & HS2-PCR-B1 & FN658719 & 569 & n.a. & CLCuMuB & AY795604.1 & 100 & 100 & \\
\hline \multirow[t]{3}{*}{$\mathrm{Ku}$} & \multirow[t]{3}{*}{ Croton } & Ku-PCR-A1 & FN645925 & 558 & n.a. & CYVMV & AJ507777.1 & 100 & 98 & \multirow{4}{*}{95.8} \\
\hline & & Ku-RCA-A1-F & FN645926 & 2761 & CYVMV & n.a. & AJ507777.1 & & & \\
\hline & & Ku-RCA-A2-p & FN645927 & 629 & n.a. & CYVMV & AJ507777.1 & 100 & 94 & \\
\hline Cgc & $\begin{array}{l}\text { Congress } \\
\text { grass }\end{array}$ & Cgc-PCR-A1 & FN645928 & 659 & n.a. & ToLCKaV & U38239.1 & 100 & 98 & \\
\hline CR & Cotton & CR-PCR-B1 & - & 516 & n.a. & CLCuMuB & DQ364230.1 & 100 & 100 & \\
\hline \multirow[t]{7}{*}{$\mathrm{L} 2$} & \multirow[t]{7}{*}{ Cotton } & L2-RCA-A1-F & FN645929 & 2759 & CLCuBuV & n.a. & AM421522.1 & & & \multirow[t]{7}{*}{99.1} \\
\hline & & L2-RCA-A2-D & FN645930 & 859 & n.a. & CLCuBuV & AM421522.1 & 100 & 100 & \\
\hline & & L2-RCA-A3-r & FN658736 & 827 & n.a. & & & & & \\
\hline & & & & $(642)$ & & CLCuBuV & AM421522.1 & 100 & 99 & \\
\hline & & & & (192) & & CLCuMuB & AY795604.1 & 99 & 98 & \\
\hline & & L2-PCR-B1 & FN658721 & 526 & n.a. & CLCuMuB & AM084379.1 & 100 & 96 & \\
\hline & & L2-RCA-b1-F & FN658722 & 1354 & n.a. & CLCuMuB & AM084379.1 & 100 & 96 & \\
\hline \multirow[t]{3}{*}{ L4K } & \multirow[t]{3}{*}{ Cotton } & L4K-PCR-A1 & FN645931 & 609 & n.a. & CLCuBuV & AM421522.1 & 100 & 100 & \multirow{8}{*}{99.2} \\
\hline & & L4K-RCA-A1-F & FN645932 & 2759 & CLCuBuV & n.a. & AM421522.1 & & & \\
\hline & & L4K-PCR-B1 & FN658723 & 568 & n.a. & CLCuMuB & AM084379.1 & 100 & 100 & \\
\hline L5K & Cotton & L5K-PCR-B1 & FN658724 & 566 & n.a. & CLCuMuB & AJ316035.1 & 100 & 100 & \\
\hline \multirow[t]{2}{*}{$\mathrm{Lc}$} & \multirow[t]{2}{*}{ Cotton } & Lc-PCR-A1 & FN645933 & 740 & n.a. & CLCuBuV & AM421522.1 & 100 & 100 & \\
\hline & & Lc-PCR-B1 & FN658725 & 205 & n.a. & CLCuMuB & AY795604.1 & 100 & 99 & \\
\hline \multirow[t]{2}{*}{ LG } & \multirow[t]{2}{*}{ Cotton } & LG-RCA-A1-p & FN645934 & 1182 & n.a. & CLCuBuV & AM421522.1 & 100 & 99 & \\
\hline & & LG-RCA-A2-p & FN645935 & 1583 & n.a. & CLCuBuV & AM421522.1 & 100 & 99 & \\
\hline
\end{tabular}




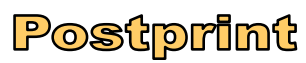

Version définitive du manuscrit publié dans / Final version of the manuscript published in : Archives of Virology, 2012, 157, 483-495. DOI: 10.1007/s00705-011-1201-y. The original publication is availalble at http://link.springer.com.

\begin{tabular}{|c|c|c|c|c|c|c|c|c|c|c|}
\hline Sample & Host plant & Sequence name & $\begin{array}{c}\text { Accession } \\
\text { number }\end{array}$ & Length & Species assignment & Closest hit & $\begin{array}{l}\text { Accession } \\
\text { number of } \\
\text { closest hit }\end{array}$ & $\begin{array}{c}\text { Coverage } \\
\text { (\%) }\end{array}$ & $\begin{array}{c}\text { Max. } \\
\text { identity } \\
(\%)\end{array}$ & $\begin{array}{c}\text { PASC } \\
(\%)\end{array}$ \\
\hline & & LG-RCA-A3-D & FN645936 & 646 & n.a. & CLCuBuV & AM421522.1 & 100 & 99 & \\
\hline & & LG-RCA-a1-F & FN658727 & 1366 & n.a. & Alphasatellite & AJ132345.1 & 100 & 99 & \\
\hline & & LG-RCA-b1-r & FN658737 & 1228 & n.a. & CLCuMuB & EU384591.1 & 95 & 97 & \\
\hline & & LG-PCR-B1 & FN658726 & 562 & n.a. & CLCuMuB & AM084379.1 & 100 & 96 & \\
\hline 22 & Cotton & 22-PCR-B1 & - & 594 & n.a. & CLCuMuB & DQ364230.1 & 99 & 100 & \\
\hline FR1 & Cotton & FR1-PCR-B1 & - & 465 & n.a. & CLCuMuB & DQ364230.1 & 99 & 100 & \\
\hline PR2 & Cotton & PR2-PCR-B1 & - & 428 & n.a. & CLCuMuB & DQ364230.1 & 100 & 99 & \\
\hline RR2 & Cotton & RR2-PCR-B1 & - & 611 & n.a. & CLCuMuB & DQ364230.1 & 99 & 100 & \\
\hline RS1 & Cotton & RS1-PCR-B1 & FN658732 & 531 & n.a. & CLCuMuB & AM084379.1 & 100 & 100 & \\
\hline \multirow[t]{2}{*}{ RS2 } & Cotton & RS2-PCR-A1 & FN645937 & 616 & n.a. & CLCuBuV & AM421522.1 & 100 & 100 & \\
\hline & & RS2-PCR-B1 & FN658731 & 527 & n.a. & CLCuMuB & AM084379.1 & 100 & 96 & \\
\hline \multirow[t]{9}{*}{ 9S1 } & Cotton & 9S1-PCR-A1 & FN645938 & 349 & n.a. & CLCuBuV & AM421522.1 & 100 & 94 & \\
\hline & & 9S1-RCA-a1-F & FN658728 & 1365 & n.a. & Alphasatellite & AJ132345.1 & 100 & 89 & \\
\hline & & 9S1-RCA-a2-F & FN658729 & 1369 & n.a. & GdSA & EU384611.1 & 100 & 97 & \\
\hline & & 9S1-RCA-a3-F & FN658730 & 1378 & n.a. & GdSA & EU384637.1 & 100 & 96 & \\
\hline & & 9S1-RCA-a4-D & FN658733 & 694 & n.a. & GdSA & EU384637.1 & 100 & 98 & \\
\hline & & 9S1-RCA-a5-D & FN658734 & 636 & n.a. & GdSA & EU384637.1 & 100 & 98 & \\
\hline & & 9S1-RCA-a6-r & FN658735 & 1287 & n.a. & GdSA & & & & \\
\hline & & & & (875) & & & EU384637.1 & 100 & 98 & \\
\hline & & & & (419) & & CLCuBuV & AJ228582.1 & 100 & 100 & \\
\hline Tri & Tribulus & Tri-PCR-B1 & - & 532 & n.a. & CLCuMuB & DQ364230.1 & 100 & 100 & \\
\hline
\end{tabular}
The sequence names indicate: sample, technique used (PCR or RCA), type of molecule (A: DNA-A, B: betasatellite, a: alphasatellite, b:
betasatellite), identification number, sequence description (F: full-length, D: defective, r: DNA-A recombinant, p: partially sequenced.

The length of the sequence is displayed along with the most similar sequence found using blastn tool against GenBank database sequences: the accession number of the best hit, along with the coverage and the identities of the alignment and the score of PASC alignment. A dash in the accession number column means that the sequence was identical to another submitted sequence. GdSA Gossypium davidsonii symptomless alphasatellite, ClGMV - Clerodendron yellow mosaic virus 
Supplemental Table 1. Fragment lengths of restricted RCA products. RCA products of all samples were digested with restriction enzymes. Fragment lengths were calculated by the Biorad Quantity One ${ }^{\circledR}$ software and rounded to the nearest 50 bases. Fragments in parentheses were cloned together. A more concise version of this table showing only those fragment lengths cloned and sequenced is shown in table 2.

\begin{tabular}{|c|c|c|c|c|c|}
\hline & Host species & AvaII & BamHI & NcoI & SalI \\
\hline 9a & Croton & $\begin{array}{llll}1750 & 1550 & 1300 & 1050 \\
900 & 400 & & \\
200 & & & \end{array}$ & $\begin{array}{|llll|}2700 & 1200 & 700 & 600 \\
\end{array}$ & N.P. & 2800 \\
\hline $9 \mathrm{~b}$ & Croton & \begin{tabular}{|llll}
1450 & 800 & 650350 \\
250 & & & \\
\end{tabular} & $\begin{array}{|llll|}2600 & 1150 & 700 & 650 \\
250 & & & \\
\end{array}$ & N.P. & 2750 \\
\hline 9c & Croton & $\begin{array}{lcc}1550 & 900 & 850600 \\
450 & 250 & \end{array}$ & $\begin{array}{|llll|}2750 & 1300 & 1200 & 800\end{array}$ & N.P. & 2700 \\
\hline 4 & Bottle Gourd & $\begin{array}{lrr}1300 & 900 & 850750 \\
600 & 250 & \\
\end{array}$ & $2750 \quad 2100$ & N.P. & 2700 \\
\hline 7 & Clerodendrum & $1050 \quad 800 \quad 500450$ & \begin{tabular}{|lll}
2100 & $(1350$ & $1100)$ \\
850 & 300
\end{tabular} & N.P. & 900 \\
\hline $1 \mathrm{a}$ & Cotton & N.A. & N.A. & N.P. & N.P. \\
\hline $1 b$ & Cotton & 1300 & 16501250 & N.P. & N.P. \\
\hline $3 n$ & Cotton & & 2850 & N.P. & N.P. \\
\hline $3 d$ & Cotton & $\begin{array}{lll}1350 & 1150 & 900 \\
400 & & \\
\end{array}$ & $\begin{array}{lllll}2750 & 1550 & 1350 & 1150 \\
700 & & & \\
\end{array}$ & N.P. & 28001400 \\
\hline $3 \mathrm{~b}$ & Cotton & N.A. & N.A. & N.P. & N.P. \\
\hline 5 & Cucumber & $1200 \quad 900$ & N.A. & N.P. & N.P. \\
\hline 8 & Guar Bean & $\begin{array}{lll}1550 & 1190 & 900\end{array}$ & \begin{tabular}{|llll}
2750 & 2100 & 1350 & 700
\end{tabular} & N.P. & 2650 \\
\hline 10a & Okra & $\begin{array}{lll}1250 & 1000 & 900750 \\
600 & 450 & \\
\end{array}$ & \begin{tabular}{|lll}
2650 & & \\
$(1550$ & $1350)$ & 1200 \\
\end{tabular} & N.P. & 16001050 \\
\hline $10 \mathrm{~b}$ & Okra & \begin{tabular}{|llll}
1500 & 1200 & 950 & 850 \\
800 & 650 & & \\
600 & 350 & 150 & \\
50 & & & \\
\end{tabular} & $\begin{array}{ll}2700 & \\
(1650 & 1450) \\
1300\end{array}$ & N.P. & 17001150 \\
\hline $10 \mathrm{c}$ & Okra & $12501050 \quad 900$ & 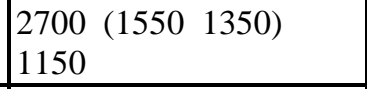 & N.P. & 16501050 \\
\hline 6 & Papaya & $\begin{array}{llll}1050 & 950 & 800 & 700 \\
650 & 550 & 500 & 200\end{array} \mid$ & N.A. & N.P. & N.P. \\
\hline HS2 & Cotton & N.A. & N.A. & N.A. & N.A. \\
\hline HS1 & Cotton & $1000 \quad 600$ & N.A. & N.P. & N.P. \\
\hline $\mathrm{Ku}$ & Croton & \begin{tabular}{|lllll}
$\begin{array}{l}1550 \\
400\end{array}$ & 1300 & 900 & 800 \\
\end{tabular} & 2750 & N.P. & 2650 \\
\hline $\mathrm{Cg}$ & Congress grass & 1450 & N.A. & N.P. & N.P. \\
\hline Cgc & Congress grass & 12501100 & 2900 & N.P. & N.P. \\
\hline $\mathrm{CR}$ & Cotton & N.A. & N.A. & N.P. & N.P. \\
\hline $\mathrm{L} 2$ & Cotton & \begin{tabular}{|llll}
1350 & 1050 & 850 & 550 \\
350 & 300 & & \\
\end{tabular} & $\begin{array}{ll}1600 & 1200 \\
900 & 650 \\
\end{array}$ & 2550 & 25001250 \\
\hline L4K & Cotton & \begin{tabular}{|llll}
1400 & 1050 & 850 & 550 \\
200 & & & \\
\end{tabular} & 16501250 & 2450 & 26001250 \\
\hline L5K & Cotton & N.A. & N.A. & N.A. & N.A. \\
\hline Lc & Cotton & N.A. & N.A. & N.P. & N.P. \\
\hline LG & Cotton & \begin{tabular}{|llll}
1250 & 1000 & 900 & 750 \\
600 & 500 & & \\
\end{tabular} & $\left.\begin{array}{|lll}1600 & (1350 & 1200\end{array}\right)$ & N.P. & 29001400 \\
\hline 130 & Cotton & N.A. & N.A. & N.P. & N.P. \\
\hline 22 & Cotton & N.A. & 2800 & N.P. & N.P. \\
\hline FR1 & Cotton & N.A. & N.A. & N.P. & N.P. \\
\hline
\end{tabular}


Version définitive du manuscrit publié dans / Final version of the manuscript published in : Archives of Virology, 2012, 157, 483-495. DOI: 10.1007/s00705-011-1201-y. The original publication is availalble at http://link.springer.com.

\begin{tabular}{|l|l|l|l|l|l|}
\hline FR2 & Cotton & N.A. & N.A. & N.P. & N.P. \\
\hline FS & Cotton & N.A. & N.A. & N.P. & N.P. \\
\hline RR1 & Cotton & N.A. & N.A. & N.P. & N.P. \\
\hline RR2 & Cotton & N.A. & N.A. & N.P. & N.P. \\
\hline RS1 & Cotton & N.A. & N.A. & N.P. & N.P. \\
\hline RS2 & Cotton & N.A. & N.A. & N.P. & N.P. \\
\hline $9 S 1$ & Cotton & $\begin{array}{l}15501250 \quad 950 \quad 850 \\
600450 \\
250\end{array}$ & $\begin{array}{l}1450 \quad(1250 \quad 1100) \\
60\end{array}$ & N.P. & 30501450 \\
& & 650 & \\
\hline Dh1 & Digeria & 1300 & N.A. & N.P. & N.P. \\
\hline Eup & Euphorbia & N.A. & N.A. & N.P. & N.P. \\
\hline Tri & Tribularia & $650 \quad 550$ & 3150 & N.P. \\
\hline
\end{tabular}




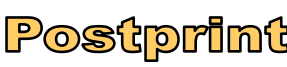

Version définitive du manuscrit publié dans / Final version of the manuscript published in : Archives of Virology, 2012, 157, 483-495. DOI: 10.1007/s00705-011-1201-y. The original publication is availalble at http://link.springer.com

Supplemental Table 2. Percent nucleotide identities between full-length DNA-A sequences analyzed

\begin{tabular}{|c|c|c|c|c|c|c|c|c|c|c|c|c|c|c|c|c|c|c|c|c|c|c|c|c|c|}
\hline & 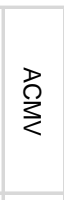 & 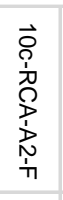 & 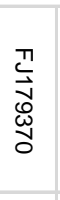 & 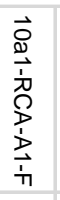 & $\begin{array}{l}\text { m } \\
\text { ज. } \\
\text { o. } \\
\text { 心 } \\
\text { d }\end{array}$ & 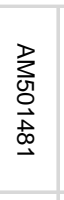 & 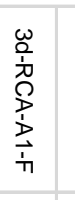 & $\begin{array}{l}\text { D } \\
\text { N్ } \\
\text { O } \\
\text { o } \\
\text { on }\end{array}$ & 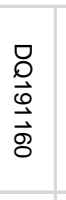 & 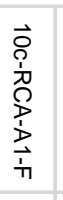 & $\begin{array}{l}\text { 芯 } \\
\text { 怘 } \\
\stackrel{N}{N}\end{array}$ & 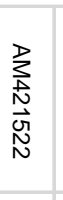 & 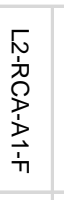 & 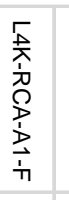 & $\begin{array}{l}\text { 己 } \\
\text { U } \\
\text { ב } \\
\text { ป }\end{array}$ & 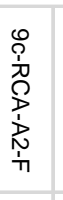 & 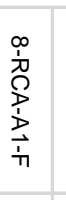 & 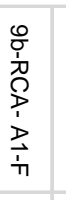 & 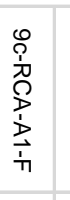 & 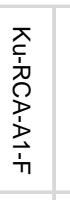 & 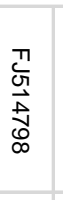 & 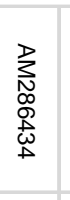 & 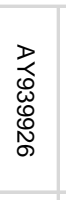 & 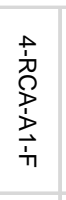 & 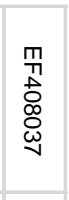 \\
\hline ACMV & & 70 & 70 & 71 & 71 & 72 & 72 & 72 & 72 & 70 & 71 & 72 & 72 & 72 & 71 & 71 & 71 & 71 & 71 & 71 & 72 & 69 & 69 & 68 & 69 \\
\hline 10c-RCA-A2-F & & & 96 & 88 & 88 & 85 & 85 & 85 & 86 & 82 & 80 & 79 & 79 & 79 & 72 & 72 & 72 & 72 & 72 & 72 & 76 & 74 & 74 & 73 & 72 \\
\hline FJ179370 & & & & 87 & 87 & 84 & 85 & 85 & 85 & 82 & 80 & 78 & 78 & 78 & 72 & 71 & 72 & 72 & 71 & 72 & 75 & 72 & 73 & 72 & 72 \\
\hline 10a1-RCA-A1-F & & & & & 99 & 84 & 84 & 84 & 84 & 80 & 80 & 78 & 78 & 78 & 73 & 72 & 73 & 73 & 73 & 73 & 80 & 73 & 73 & 74 & 72 \\
\hline EU589392 & & & & & & 83 & 84 & 83 & 84 & 80 & 80 & 78 & 78 & 78 & 72 & 72 & 72 & 73 & 72 & 72 & 79 & 73 & 73 & 73 & 71 \\
\hline AM501481 & & & & & & & 100 & 99 & 94 & 82 & 84 & 84 & 84 & 84 & 74 & 73 & 74 & 74 & 73 & 74 & 79 & 73 & 73 & 72 & 72 \\
\hline 3d-RCA-A1-F & & & & & & & & 100 & 94 & 82 & 84 & 84 & 84 & 84 & 74 & 73 & 74 & 74 & 73 & 74 & 79 & 73 & 73 & 72 & 72 \\
\hline GQ220850 & & & & & & & & & 94 & 82 & 84 & 84 & 84 & 84 & 74 & 73 & 74 & 74 & 73 & 74 & 79 & 73 & 73 & 72 & 72 \\
\hline DQ191160 & & & & & & & & & & 83 & 84 & 87 & 87 & 87 & 72 & 72 & 72 & 73 & 72 & 73 & 77 & 73 & 73 & 73 & 72 \\
\hline 10c-RCA-A1-F & & & & & & & & & & & 89 & 78 & 78 & 78 & 77 & 77 & 77 & 77 & 77 & 77 & 75 & 72 & 72 & 72 & 70 \\
\hline FJ159262 & & & & & & & & & & & & 80 & 80 & 80 & 77 & 77 & 76 & 77 & 77 & 77 & 75 & 71 & 72 & 71 & 70 \\
\hline AM421522 & & & & & & & & & & & & & 99 & 99 & 76 & 76 & 76 & 76 & 76 & 76 & 81 & 73 & 74 & 73 & 71 \\
\hline L2-RCA-A1-F & & & & & & & & & & & & & & 100 & 76 & 76 & 76 & 76 & 76 & 76 & 81 & 73 & 74 & 73 & 72 \\
\hline L4K-RCA-A1-F & & & & & & & & & & & & & & & 76 & 76 & 76 & 76 & 76 & 76 & 81 & 73 & 74 & 73 & 72 \\
\hline AJ507777 & & & & & & & & & & & & & & & & 96 & 95 & 96 & 96 & 96 & 81 & 71 & 72 & 71 & 75 \\
\hline 9c-RCA-A2-F & & & & & & & & & & & & & & & & & 95 & 95 & 96 & 96 & 81 & 72 & 72 & 71 & 74 \\
\hline 8-RCA-A1-F & & & & & & & & & & & & & & & & & & 96 & 97 & 97 & 81 & 72 & 72 & 71 & 75 \\
\hline 9b-RCA- A1-F & & & & & & & & & & & & & & & & & & & 98 & 98 & 81 & 72 & 72 & 72 & 75 \\
\hline 9c-RCA-A1-F & & & & & & & & & & & & & & & & & & & & 98 & 81 & 72 & 72 & 71 & 75 \\
\hline Ku-RCA-A1-F & & & & & & & & & & & & & & & & & & & & & 81 & 72 & 72 & 71 & 75 \\
\hline FJ514798 & & & & & & & & & & & & & & & & & & & & & & 74 & 75 & 75 & 73 \\
\hline AM286434 & & & & & & & & & & & & & & & & & & & & & & & 96 & 90 & 70 \\
\hline AY939926 & & & & & & & & & & & & & & & & & & & & & & & & 91 & 71 \\
\hline 4-RCA-A1-F & & & & & & & & & & & & & & & & & & & & & & & & & 71 \\
\hline
\end{tabular}




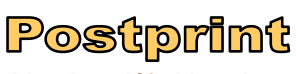

Version définitive du manuscrit publié dans / Final version of the manuscript published in : Archives of Virology, 2012, 157, 483-495. DOI: 10.1007/s00705-011-1201-y. The original publication is availalble at http://link.springer.com

Supplemental Table 3. Percent nucleotide identities between partial DNA-A sequences analyzed.

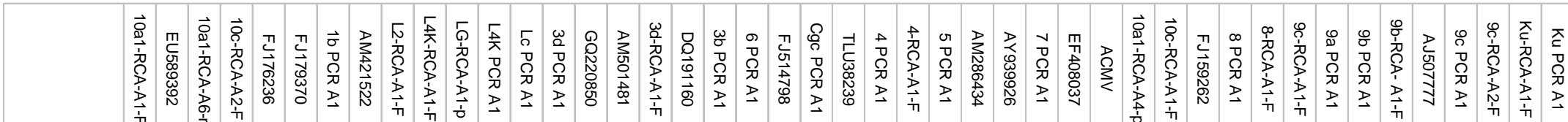

10a1-RCA-A1-F EU589392

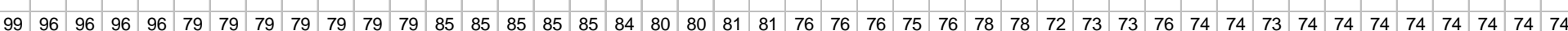

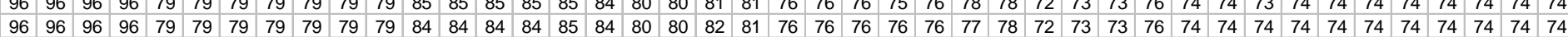

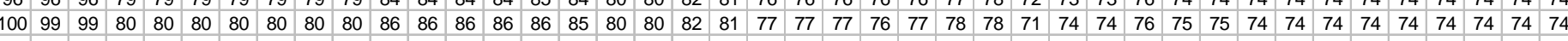

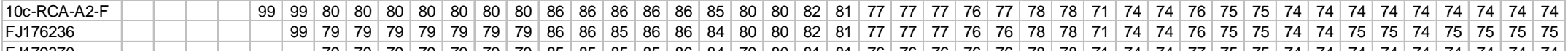

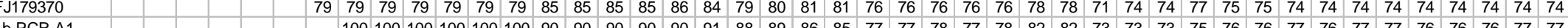

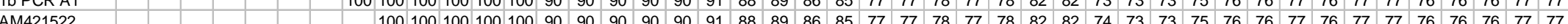

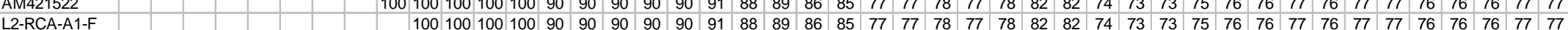

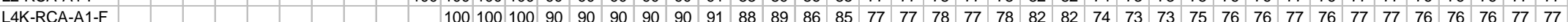

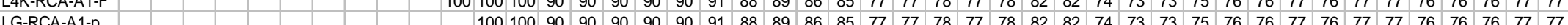

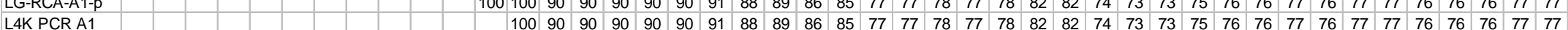

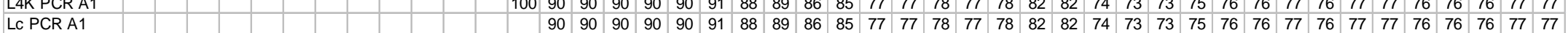

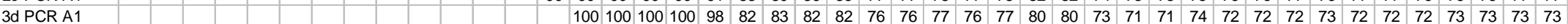

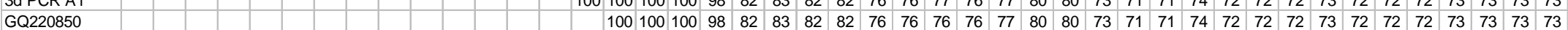

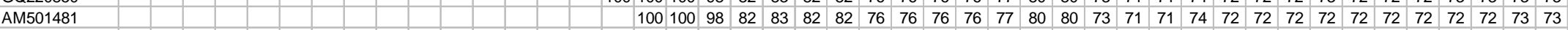
\begin{tabular}{l|l|l|l|lllllllllllllllllllllllllll} 
& 100 & 98 & 82 & 83 & 82 & 82 & 76 & 76 & 77 & 76 & 77 & 80 & 80 & 73 & 71 & 71 & 74 & 72 & 72 & 72 & 73 & 72 & 72 & 72 & 73 & 73 & 73 & 73
\end{tabular}

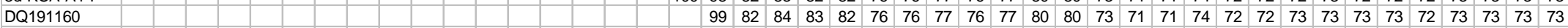

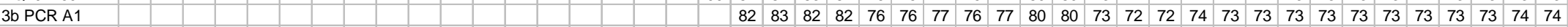

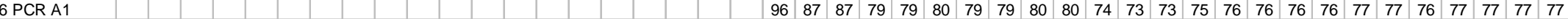
$\begin{array}{llllllllllllllllllllllllllll}87 & 87 & 79 & 79 & 80 & 79 & 79 & 80 & 80 & 74 & 73 & 73 & 75 & 76 & 76 & 76 & 76 & 77 & 77 & 76 & 77 & 77 & 77 & 77 \\ 86 & 86 & 79 & 79 & 80 & 79 & 79 & 81 & 82 & 74 & 72 & 72 & 76 & 77 & 77 & 77 & 77 & 77 & 77 & 77 & 77 & 77 & 77 & 77\end{array}$ $\begin{array}{llllllllllllllllllllllll} & 87\end{array}$

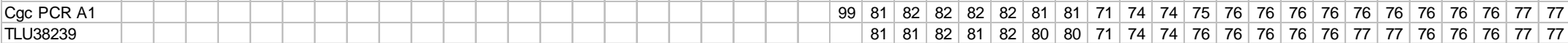

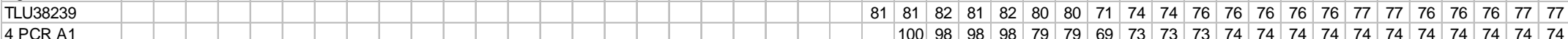
PCR A \begin{tabular}{lllllllllllllllllllllllll} 
& 98 & 98 & 79 & 79 & 69 & 73 & 73 & 73 & 74 & 74 & 74 & 74 & 74 & 74 & 74 & 74 & 74 & 74 & 74 \\
\hline 98 & 98 & 97 & 79 & 79 & 69 & 73 & 73 & 73 & 74 & 74 & 74 & 74 & 74 & 74 & 74 & 74 & 74 & 74 & 74
\end{tabular} 4-RCA-A1-F \begin{tabular}{l|l|l|l|l|l|l|l|l|l|l|l|l|l|l|l|l|l|l|l}
98 & 98 & 97 & 79 & 79 & 69 & 73 & 73 & 73 & 74 & 74 & 74 & 74 & 74 & 74 & 74 & 74 & 74 & 74 & 74 \\
\hline & 99 & 98 & 79 & 79 & 69 & 73 & 73 & 74 & 74 & 74 & 74 & 74 & 75 & 75 & 74 & 74 & 74 & 74 & 74 \\
& & 97 & 79 & 79 & 68 & 73 & 73 & 73 & 74 & 74 & 74 & 74 & 74 & 74 & 74 & 74 & 74 & 74 & 74
\end{tabular} SPCR A1 AM286434 \begin{tabular}{llllllllllllllllllllllllll}
97 & 79 & 79 & 68 & 73 & 73 & 73 & 74 & 74 & 74 & 74 & 74 & 74 & 74 & 74 & 74 & 74 & 74 \\
\hline
\end{tabular} AY 939926 7PCRA1 \begin{tabular}{llllllllllllllllllll} 
& 79 & 69 & 73 & 73 & 73 & 74 & 74 & 74 & 74 & 74 & 74 & 74 & 74 & 74 & 74 & 74 \\
\hline
\end{tabular} \begin{tabular}{|l|l|l|l|l|l|l|l|l|l|l|l|l|l|l|l|l|l|l|l|l|l|l|l|}
\hline 72 & 72 & 72 & 73 & 73 & 73 & 74 & 74 & 74 & 74 & 73 & 74 & 74 & 73 & 73 \\
\hline 72 & 72 & 72 & 73 & 73 & 73 & 74 & 74 & 74 & 74 & 73 & 74 & 74 & 74 & 74 \\
\hline
\end{tabular} ACMV \begin{tabular}{lllllllllllllll}
72 & 72 & 73 & 73 & 73 & 74 & 74 & 74 & 74 & 73 & 74 & 74 & 74 & 74 \\
\hline 69 & 69 & 70 & 70 & 70 & 70 & 70 & 70 & 70 & 70 & 70 & 70 & 70 & 70
\end{tabular} \begin{tabular}{lll|l|l|l|lllllllll}
69 & 70 & 70 & 70 & 70 & 70 & 70 & 70 & 70 & 70 & 70 & 70 & 70 \\
\hline
\end{tabular} 10a1-RCA-A4-P

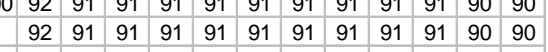
\begin{tabular}{lllllllllll}
96 & 96 & 96 & 96 & 96 & 96 & 96 & 96 & 96 & 96 & 96 \\
\hline
\end{tabular} FJ159262 \begin{tabular}{|l|l|l|l|l|l|l|l|l|l|l|}
100 & 98 & 98 & 99 & 99 & 98 & 99 & 99 & 98 & 98 \\
\hline 98 & 98 & 99 & 99 & 98 & 99 & 99 & 98 & 98 \\
\hline
\end{tabular} 8 PCR A1 \begin{tabular}{llllllllll}
98 & 98 & 99 & 99 & 98 & 99 & 99 & 98 & 98 \\
\hline & 98 & 99 & 99 & 99 & 99 & 99 & 98 & 98
\end{tabular}

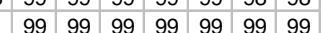
$\begin{array}{rrrrrr}99 & 99 & 99 & 99 & 99 & 99 \\ 100 & 99 & 100 & 100 & 99 & 99\end{array}$ 9a PCR A1 9b PCR A1 $\begin{array}{lllll}99 & 100 & 100 & 99 & 99 \\ 99 & 100 & 100 & 99 & 99\end{array}$ AJ507777 \begin{tabular}{l|l|l|l|}
99 & 99 & 99 & 99 \\
\hline
\end{tabular} 9C PCR A1 \begin{tabular}{l|l|l|}
\hline 09 & 99 \\
\hline 99 & 99
\end{tabular} MC-RCA-A2-F 


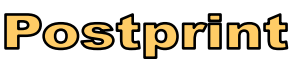

Version définitive du manuscrit publié dans / Final version of the manuscript published in : Archives of Virology, 2012, 157, 483-495. DOI: 10.1007/s00705-011-1201-y. The original publication is availalble at http://link.springer.com.

Supplemental Table 4. Percent nucleotide identities between partial betasatellite sequences analyzed.

\begin{tabular}{|c|c|c|c|c|c|c|c|c|c|c|c|c|c|c|c|c|c|c|}
\hline & 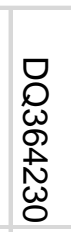 & $\begin{array}{l}\searrow \\
\vdots \\
0 \\
0 \\
o \\
\circ \\
1\end{array}$ & $\begin{array}{l}I \\
C D \\
\mapsto \\
D \\
D \\
D \\
D \\
D\end{array}$ & $\begin{array}{l}I \\
\mathcal{N} \\
N \\
D \\
D \\
D \\
D \\
D\end{array}$ & 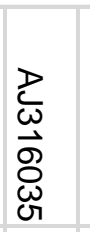 & $\begin{array}{l}\bar{\Sigma} \\
\frac{\pi}{\lambda} \\
\tilde{D} \\
D \\
D \\
\square\end{array}$ & $\begin{array}{l}\omega \\
\varrho \\
D \\
\bigcap \\
D \\
\square \\
\mapsto\end{array}$ & $\begin{array}{l}D \\
o \\
0 \\
0 \\
D \\
N \\
N\end{array}$ & 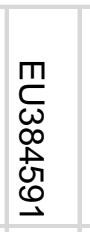 & 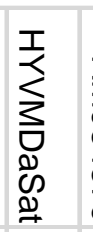 & $\begin{array}{l}D \\
z \\
o \\
0 \\
\omega \\
d \\
0\end{array}$ & 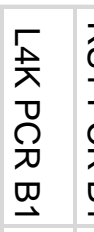 & 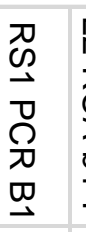 & 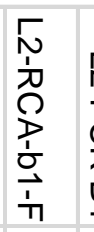 & 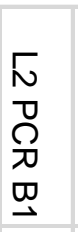 & $\begin{array}{l}\square \\
\\
D \\
D \\
D \\
D \\
P\end{array}$ & 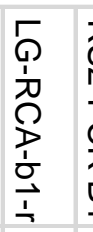 & 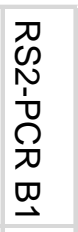 \\
\hline DQ364230 & & 98 & 399 & 99 & 96 & 94 & 85 & 85 & 78 & 56 & 96 & 93 & 92 & 93 & 93 & 93 & 93 & 92 \\
\hline AY795604 & & & 98 & 98 & 97 & 94 & 84 & 84 & 78 & 56 & 94 & 91 & 90 & 91 & 91 & 91 & 91 & 91 \\
\hline HS1 PCR B1 & & & & 100 & 96 & 94 & 85 & 85 & 78 & 56 & 95 & 92 & 91 & 92 & 92 & 92 & 92 & 92 \\
\hline HS2 PCR B1 & & & & & 96 & 94 & 85 & 85 & 78 & 55 & 94 & 92 & 91 & 92 & 92 & 92 & 92 & 91 \\
\hline AJ316035 & & & & & & 97 & 83 & 83 & 78 & 55 & 93 & 90 & 89 & 90 & 90 & 90 & 90 & 90 \\
\hline L5K PCR B1 & & & & & & & 84 & 84 & 80 & 56 & 91 & 89 & 88 & 89 & 89 & 89 & 89 & 89 \\
\hline 3d PCR B1 & & & & & & & & 100 & 85 & 54 & 81 & 84 & 83 & 84 & 84 & 84 & 84 & 84 \\
\hline AY820772 & & & & & & & & & 85 & 54 & 81 & 84 & 83 & 84 & 84 & 84 & 84 & 84 \\
\hline EU384591 & & & & & & & & & & 54 & 76 & 77 & 77 & 77 & 77 & 77 & 77 & 77 \\
\hline HYVMDaSat & & & & & & & & & & & 56 & 56 & 57 & 57 & 57 & 56 & 56 & 57 \\
\hline AM084379 & & & & & & & & & & & & 96 & 95 & 96 & 96 & 96 & 96 & 95 \\
\hline L4K PCR B1 & & & & & & & & & & & & & $99:$ & 100 & 100 & 100 & 100 & 99 \\
\hline RS1 PCR B1 & & & & & & & & & & & & & & 98 & 98 & 98 & 98 & 98 \\
\hline L2-RCA-b1-F & & & & & & & & & & & & & & & 100 & 100 & 100 & 100 \\
\hline L2 PCR B1 & & & & & & & & & & & & & & & & 1001 & 100 & 100 \\
\hline LG PCR B1 & & & & & & & & & & & & & & & & & 100 & 100 \\
\hline LG-RCA-b1-r & & & & & & & & & & & & & & & & & & 100 \\
\hline
\end{tabular}




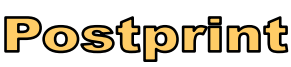

Version définitive du manuscrit publié dans / Final version of the manuscript published in : Archives of Virology, 2012, 157, 483-495. DOI: 10.1007/s00705-011-1201-y. The original publication is availalble at http://link.springer.com.

Supplemental Table 5. Percent nucleotide identities between full-length alphasatellite sequences analyzed.

\begin{tabular}{|c|c|c|c|c|c|c|c|c|c|c|c|c|c|c|c|c|c|c|c|c|c|c|c|c|}
\hline & 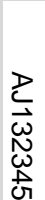 & 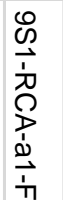 & 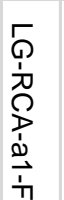 & 点 & 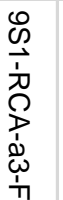 & 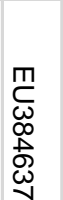 & 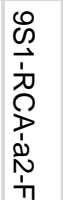 & 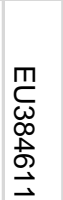 & 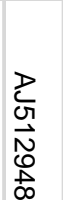 & 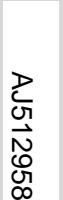 & 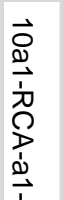 & 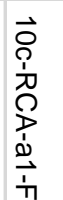 & 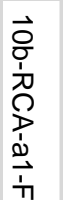 & 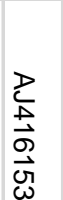 & 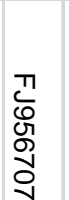 & 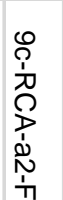 & 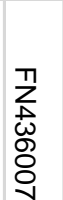 & 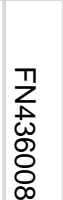 & 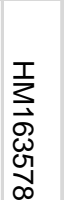 & ग̃ & 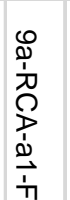 & 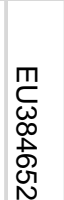 & 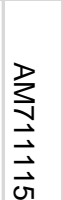 & $\begin{array}{l}\text { Th } \\
\text { o } \\
\text { ○ } \\
0 \\
0\end{array}$ \\
\hline AJ132345 & & 90 & 90 & 83 & 78 & 78 & 78 & 78 & 79 & 79 & ' 80 & 80 & 80 & 47 & 46 & 47 & 46 & 46 & 48 & 42 & 57 & 59 & 75 & 75 \\
\hline 9S1-RCA-a1-F & & & 100 & 82 & 76 & 77 & 78 & 78 & 78 & 79 & 81 & 81 & 81 & 47 & 46 & 48 & 45 & 46 & 47 & 44 & 57 & 59 & 76 & 75 \\
\hline LG-RCA-a1-F & & & & 82 & 76 & 77 & 78 & 78 & 78 & 79 & 81 & 81 & 81 & 47 & 46 & 48 & 45 & 46 & 47 & 44 & 57 & 59 & 76 & 75 \\
\hline AM711116 & & & & & 84 & 83 & 84 & 84 & 80 & 80 & 85 & 85 & 85 & 48 & 48 & 47 & 46 & 47 & 47 & 43 & 57 & 59 & 75 & 76 \\
\hline 9S1-RCA-a3-F & & & & & & 97 & 95 & 93 & 78 & 78 & 78 & 78 & 78 & 48 & 48 & 48 & 46 & 46 & 47 & 44 & 59 & 61 & 74 & 75 \\
\hline EU384637 & & & & & & & 95 & 94 & 78 & 78 & 78 & 78 & 78 & 48 & 48 & 49 & 47 & 47 & 48 & 45 & 59 & 62 & 74 & 76 \\
\hline 9S1-RCA-a2-F & & & & & & & & 98 & 78 & 78 & 79 & 79 & 79 & 48 & 48 & 48 & 46 & 47 & 47 & 45 & 59 & 61 & 74 & 75 \\
\hline EU384611 & & & & & & & & & 77 & 77 & 79 & 79 & 79 & 48 & 48 & 48 & 46 & 46 & 47 & 44 & 58 & 60 & 74 & 75 \\
\hline AJ512948 & & & & & & & & & & 96 & 86 & 86 & 86 & 49 & 48 & 48 & 46 & 45 & 46 & 46 & 58 & 60 & 78 & 86 \\
\hline AJ512958 & & & & & & & & & & & 86 & 86 & 86 & 49 & 48 & 48 & 46 & 45 & 46 & 45 & 58 & 59 & 79 & 86 \\
\hline 10a1-RCA-a1-F & & & & & & & & & & & & 100 & 100 & 48 & 48 & 48 & 46 & 45 & 46 & 44 & 57 & 59 & 76 & 80 \\
\hline 10c-RCA-a1-F & & & & & & & & & & & & & 100 & 48 & 48 & 48 & 46 & 45 & 46 & 44 & 57 & 59 & 76 & 80 \\
\hline 10b-RCA-a1-F & & & & & & & & & & & & & & 48 & 48 & 48 & 46 & 45 & 46 & 44 & 57 & 59 & 76 & 80 \\
\hline AJ416153 & & & & & & & & & & & & & & & 93 & 55 & 53 & 53 & 53 & 45 & 45 & 47 & 46 & 48 \\
\hline FJ956707 & & & & & & & & & & & & & & & & 55 & 53 & 52 & 52 & 44 & 44 & 46 & 46 & 48 \\
\hline 9c-RCA-a2-F & & & & & & & & & & & & & & & & & 68 & 66 & 68 & 44 & 45 & 46 & 47 & 49 \\
\hline FN436007 & & & & & & & & & & & & & & & & & & 76 & 73 & 41 & 43 & 44 & 46 & 47 \\
\hline FN436008 & & & & & & & & & & & & & & & & & & & 72 & 42 & 44 & 44 & 44 & 47 \\
\hline HM163578 & & & & & & & & & & & & & & & & & & & & 40 & 45 & 46 & 46 & 47 \\
\hline CFDV & & & & & & & & & & & & & & & & & & & & & 47 & 47 & 45 & 46 \\
\hline 9a-RCA-a1-F & & & & & & & & & & & & & & & & & & & & & & 92 & 57 & 57 \\
\hline EU384652 & & & & & & & & & & & & & & & & & & & & & & & 60 & 60 \\
\hline AM711115 & & & & & & & & & & & & & & & & & & & & & & & & 81 \\
\hline
\end{tabular}




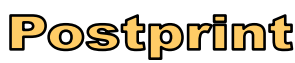

Version définitive du manuscrit publié dans / Final version of the manuscript published in : Archives of Virology, 2012, 157, 483-495. DOI: 10.1007/s00705-011-1201-y. The original publication is availalble at http://link.springer.com.

Supplemental Table 6. The P-values measured by the different methods used by RDP 3.27 for the recombination event at nucleotide positions 1108 and 1458 resulting in molecule 10c-RCA-A1-F, shown in Fig. 8.

\begin{tabular}{ll}
\hline Method & $P$-value \\
\hline RDP & $1.68 \times 10^{-11}$ \\
GENECONV & $4.39 \times 10^{-04}$ \\
Bootscan & $1.70 \times 10^{-09}$ \\
Maxchi & $4.03 \times 10^{-09}$ \\
Chimaera & $4.33 \times 10^{-10}$ \\
SiScan & $1.58 \times 10^{-11}$ \\
PhylPro & Ns \\
LARD & Ns \\
3Seq & $1.78 \times 10^{-09}$ \\
\hline
\end{tabular}




\section{Suppl. Fig. 1}

a) DNA-A

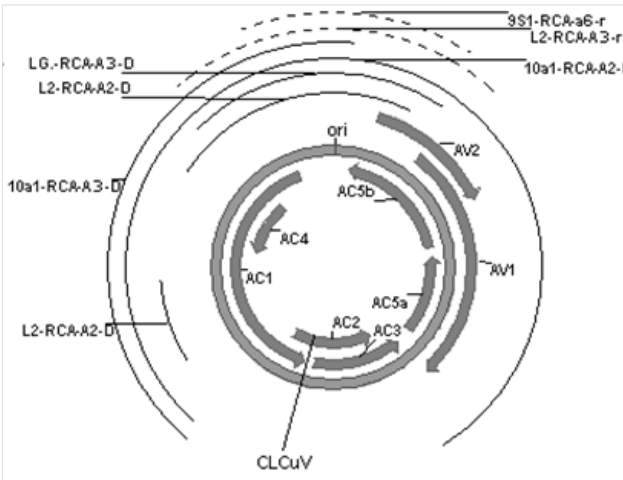

d) LG-RCA-b1-r

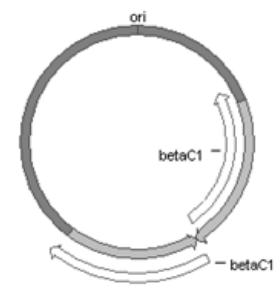

b) alphasatellite

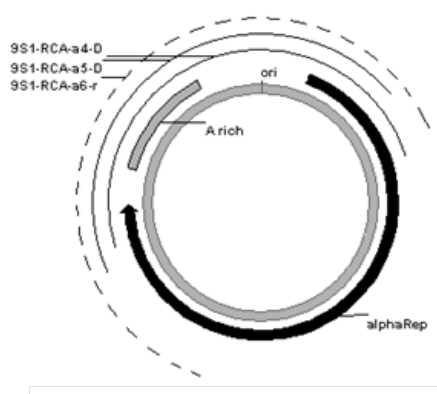

e) L2-RCA-A3-r

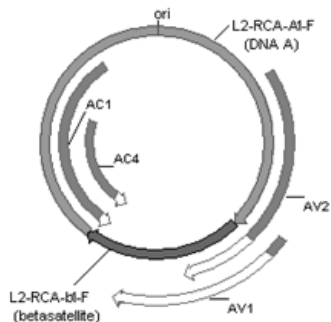

c) betasatellite

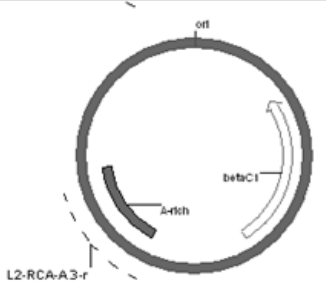

f) 9S1-RCA-a6-r

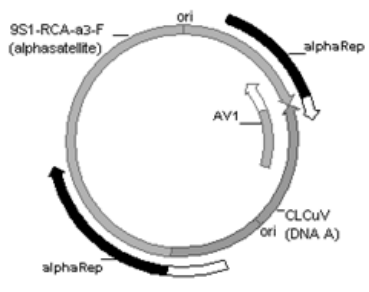

Suppl Fig. 1 Genome maps of unusual or novel circular DNAs. (a) Begomoviral full-length DNA-A showing the positions of the predicted genes (shown by arrows) encoded in both virion and complementary sense. Externally, the positions on the complete genome of the defective molecules are shown by full lines, and the segments in recombinants by dashed lines. (b) Begomoviral full-length alphasatellite DNA showing the positions of the alphaRep gene and the A-rich region. Externally, the positions on the complete genome of the defective molecules are shown by full lines, and the segments in recombinants by dashed lines. (c) Begomoviral fulllength betasatellite showing the positions of the betaC 1 gene and the A-rich region. Externally the position on the complete molecule of the segment present in recombinant L2-RCA-A3-r is shown. (d) Molecule LG-RCA-b1-r, a recombinant betasatellite molecule. The sequence in light gray is an inverted repeat. The upper inverted betaC1 ORF is truncated. (e) Molecule L2-RCAA3-r, a recombinant between the DNA-A molecule L2-RCA-A1-F and the betasatellite molecule L2-RCA-b1-F. Four DNA-A ORFs are shown, which terminate inside the betasatellite-derived sequence. The positions on the DNA-A and on the betasatellite of the parental sequences are shown in figure 7a and7b. (f) Molecule 9S1-RCA-a6-r, a recombinant between the alphasatellite molecule 9S1-RCA-a3-F and a CLCuV DNA-A molecule (whose sequence is inverted). The two origins of replication (ori) are shown, along with the ORFs, whose partial sequence is identical to the alphaRep and the AV1 genes. The positions on the DNA-A and on the alphasatellite DNA of the parental sequences are shown in figure $7 \mathrm{a}$ and $7 \mathrm{c}$. Maps not shown to scale.

Please move to SOM 